\title{
The roles of signal transducer and activator of transcription factor 3 in tumor angiogenesis
}

\author{
Peng Gao ${ }^{1, *}$, Na Niü ${ }^{2, *}$, Tianshu $\mathrm{Wei}^{1}$, Hideto Tozawa ${ }^{3}$, Xiaocui Chen ${ }^{1}$, Caiqing \\ Zhang ${ }^{4}$, Jiandong Zhang ${ }^{5}$, Youichiro Wada ${ }^{3}$, Carolyn M. Kapron ${ }^{6}$ and Ju Liu ${ }^{1}$ \\ ${ }^{1}$ Medical Research Center, Shandong Provincial Qianfoshan Hospital, Shandong University, Jinan, Shandong, China \\ ${ }^{2}$ Department of Pediatrics, Shandong Provincial Hospital Affiliated to Shandong University, Jinan, Shandong, China \\ ${ }^{3}$ The Research Center for Advanced Science and Technology, Isotope Science Center, The University of Tokyo, Meguro-ku, \\ Tokyo, Japan \\ ${ }^{4}$ Department of Respiratory Medicine, Shandong Provincial Qianfoshan Hospital, Shandong University, Jinan, Shandong, \\ China \\ ${ }^{5}$ Department of Radiation Oncology, Shandong Provincial Qianfoshan Hospital, Shandong University, Jinan, Shandong, China \\ ${ }^{6}$ Department of Biology, Trent University, Peterborough, Ontario, Canada \\ *These authors contributed equally to this work
}

Correspondence to: Ju Liu, email: ju.liu@sdu.edu.cn

Keywords: STAT3, tumor angiogenesis, transcriptional regulation, endothelial cells

Received: June 28, $2017 \quad$ Accepted: July 26, $2017 \quad$ Published: August 04, 2017

Copyright: Gao et al. This is an open-access article distributed under the terms of the Creative Commons Attribution License 3.0 (CC BY $3.0)$, which permits unrestricted use, distribution, and reproduction in any medium, provided the original author and source are credited.

\section{ABSTRACT}

Angiogenesis is the development of new blood vessels, which is required for tumor growth and metastasis. Signal transducer and activator of transcription factor 3 (STAT3) is a transcription factor that regulates a variety of cellular events including proliferation, differentiation and apoptosis. Previous studies revealed that activation of STAT3 promotes tumor angiogenesis. In this review, we described the activities of STAT3 signaling in different cell types involved in angiogenesis. Particularly, we elucidated the molecular mechanisms of STAT3-mediated gene regulation in angiogenic endothelial cells in response to external stimulations such as hypoxia and inflammation. The potential for STAT3 as a therapeutic target was also discussed. Overall, this review provides mechanistic insights for the roles of STAT3 signaling in tumor angiogenesis.

\section{INTRODUCTION}

Angiogenesis is defined as the development of new capillaries from pre-existing vessels $[1,2]$. Physiological angiogenesis is crucial for embryo development, wound healing, and ovarian cycle. Pathological angiogenesis is associated with various diseases, including diabetes, arthritis, macula degeneration and cancer [3, 4]. As solid tumor requires new vessels to supply the blood with nutrients and oxygen, tumor angiogenesis is essential for tumor growth and became a key target for chemotherapy $[5,6]$.

Generally, when the diameter of a tumor is larger than 2 millimeters, the tissue penetration can no longer sustain tumor growth, resulting in hypoxia in the microenvironment $[7,8]$. In hypoxic condition, tumor cells produce and secrete pro-angiogenic cytokines, which activate endothelial cells (ECs), the inner layer of the existing blood vessels $[9,10]$. The pro-angiogenic cytokines include basic fibroblast growth factor (bFGF), vascular endothelial growth factor (VEGF), and plateletderived growth factor (PDGF) [11-13], all of which have specific receptors on endothelial cells [14]. Upon activation by growth factor-receptor interaction, endothelial cells sprout by migration and proliferation [15]. Tumor cells and ECs both secrete matrix metalloproteinases (MMPs), which degrade basement membranes and the extracellular matrix (ECM) connecting with ECs [16]. The primary sprouts form tubes and then capillary loops, followed by recruitment of pericytes, synthesis of a new basement membrane and vessel maturation [17]. Tumor vasculature 
usually lacks of pericytes and intact basement membrane structure, which is convenient for additional tumor angiogenesis and metastasis [18].

VEGF is the most potent pro-angiogenic factor [19]. The expression of VEGF is controlled by cascades of cell signaling events and transcriptional factors. Signal transducer and activator of transcription factor 3 (STAT3) is one of the angiogenesis-related transcription factors [20]. In many types of tumors, activation of STAT3 increases the expression of VEGF and MMPs, promoting tumor angiogenesis. In endothelial cells, STAT3 transduces VEGF signals, and promotes EC proliferation, migration, and survival. Targeting STAT3 for tumor angiogenesis becomes a promising strategy. In this review, we will focus on the roles of STAT3 in mediating the expression of angiogenesis-related genes and discuss the molecular mechanisms behind STAT3-regulated tumor angiogenesis.

\section{STAT family members}

The STAT family includes 7 members: STAT1, STAT2, STAT3, STAT4, STAT5A, STAT5B, and STAT6; all of which act as transcription factors [20-22]. STAT family members share five highly homologous domains including a N-terminal domain, an STAT_ $\alpha$ domain, a DNA-binding domain, an Src homology 2 (SH2) domain, and a C-terminal domain with transactivation activity (Figure 1A). The human Stat3 gene is located on chromosome 17q21.2 [23]. STAT3 protein is composed of 770 amino acids with a molecular weight of 92 kilo-dalton (KDa). There are two phosphorylation sites tyrosine 705 and serine 727 on the C-terminal domain of STAT3. The tyrosine is necessary for STAT activation, and the serine phosphorylation occurs after tyrosine phosphorylation. The serine site of STAT3 might be phosphorylated alone, but this phosphorylation does not configure STAT3 transactivation [23].

\section{STAT3 signal transduction and STAT3-regulated transcription}

The activation of STAT3 is initiated by the binding of growth factors and cytokines with their receptors. As shown in Figure 1B, VEGF and epidermal growth factor (EGF) bind to their receptors and promote the dimerization of receptors [24, 25]. VEGFR and EGFR are both receptor tyrosine kinases (RTKs). The dimerized receptors autophosphorylate each other and then phosphorylate the non-receptor protein tyrosine kinases janus kinase 2 (JAK2) and c-Src kinase. The JAK2 and c-Src kinase in turn phosphorylate STAT3 at tyrosine 705, leading to STAT3 dimer or formation and translocation into the nucleus [26]. The serine 727 may also be phosphorylated by mitogen-activated protein kinase (MAPK) and protein kinase $\mathrm{C}(\mathrm{PKC})$, but it is not as essential as the tyrosine 705 for STAT3 activation [27]. The interleukin-6 (IL-6) signal also transduce though JAK2 as shown in Figure 1B. The receptor of IL-6 is a complex which contains IL-6 receptor subunit (IL6R) and IL-6 signal transducer glycoprotein 130 (gp130). The complex activates STAT3 in a JAK2 dependent way [28]. The phosphorylated STAT3 translocates into nucleus and regulates the target genes by recognizing specific DNA sequences known as the interferon -gamma activated sequence (GAS), TTCnnnGAA [26, 29]. While most STATs proteins require phosphorylation and dimerization before transport into nucleus, STAT3 may translocate into the nucleus as a monomer. Once entering into the nucleus, monomeric aphosphotyrosine STAT3 (STAT3 ${ }_{\mathrm{aPTyr}}$ ) binds to p65 (RELA) and p50, and the complex competitively inhibits the binding of NF- $\kappa \mathrm{B}$ p 65 homodimer to its targeted DNA elements, thus preventing NF- $\kappa \mathrm{B}$ mediated gene expression during the acute-phase response [30]. Other STAT family members do not inhibit NF- $\kappa$ B targeted gene expression. In addition, STAT3 exists in mitochondria of mature central nervous system (CNS) neurons and provides an ancillary role for axon re-growth [31]. In mouse embryonic fibroblasts (MEF), STAT3 reduces reactive oxygen species (ROS) production by binding to cyclophilin D (CypD) in the mitochondria [32].

\section{Modulation of STAT3 activation}

Recent findings suggest that pyruvate kinase M2 (PKM2), a glycolysis enzyme, directly activates STAT3 $[33,34]$. PKM2 catalyzes phosphoenolpyruvate (PEP) to pyruvate in a tetramer form in both aerobic and anaerobic glycolysis [35]. In tumor cells, the dimeric PKM2 is the main form of existence [36-38]. The PKM2 dimers act as a protein kinase to phosphorylate STAT3 at tyrosine 705 where PEP is the donor to provide phosphate [34]. The nuclear localization signal (NLS) of PKM2 facilitates its translocation into the nucleus, thus is essential for PKM2 mediated STAT3 activation [37]. The PKM2/ STAT3 pathway promotes cell proliferation and migration $[39,40]$. In colorectal cancer (CRC) cells, inhibition of STAT3 will significantly restrict PKM2 induced cytokines production and cell proliferation [40]. In liver cancer cells, over-expression of PKM2 increases proliferation and transfection with siRNA of PKM2 decreases proliferation, while phosphorylation of STAT3 at Y705 but not S727 is enhanced by PKM2 [41]. PKM2 is also reported to be interacting with STAT3 to up-regulate Mek5 expression $[35,42]$. Over-expression of PKM2 up-regulates MMP2, MMP9, and N-cadherin, while inhibition of STAT3 abolishes these effects of PKM2 [39].

In addition to the canonical and non-canonical phosphorylation of STAT3, acetylation of STAT3 is a post-translational modification of STAT3 in response to cytokine stimulation [43]. Oncostatin M (OSM), IL-6, and interferon- $\alpha$ (IFN- $\alpha)$ are all reported to increase STAT3 acetylation by promoting the interaction of histone 


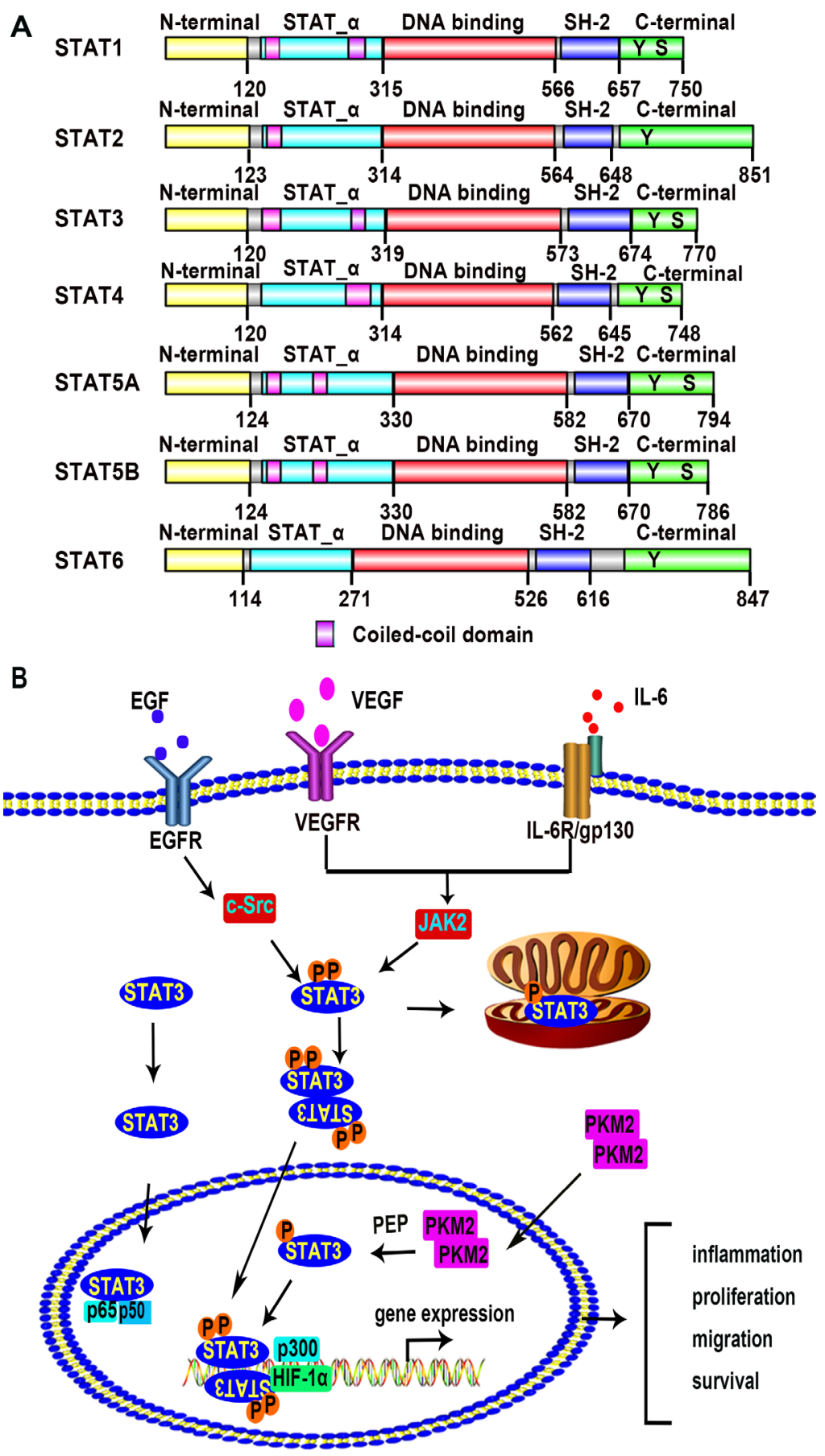

Figure 1: The STAT family members and the STAT3 signaling pathway. (A) A conceptual diagram showing the structure of STAT family members. There are seven members in the STAT family including STAT1, STAT2, STAT3, STAT4, STAT5A, STAT5B, and STAT6. STAT family members are sharing five highly homologous domains including a N-terminal domain, an STAT_ $\alpha$ domain, a DNAbinding domain, an SH2 domain, and a C-terminal domain with transactivation activity. There are some amino acid residues which are crucial for STAT dimerization and transactivation, such as tyrosine 705 (dimerization and DNA binding) and serine 727 (transactivation) residue. These data come from the database of Pfam which belongs to the European Molecular Biology Laboratory-The European Bioinformatics Institute (EMBL-EBI). (http://pfam.xfam.org/protein/P42224/P52630/P40763/Q14765/P42229/P51692/P42226). (B) Schematic depiction of the STAT3 signaling pathway. Extracellular signals including growth factors and cytokines activate STAT3. Binding of these signal factors to their cell surface receptors results in phosphorylation of STAT3 at tyrosine 705 and serine 727 . STAT3 monomers then dimerize, binding with each other at the SH2 domain. After translocation into the nucleus, the dimerized STAT3 molecule binds to the promoter region of target genes with or without co-factors, modulating transcription of the genes related to inflammation, cellular proliferation, migration, survival. Unphosphorylated STAT3 monomers also translocate into the nucleus and form a complex with p65 and p50 to regulate NF-אB signal pathway. PKM2 dimers act as a protein kinase to phosphorylate STAT3 at tyrosine 705 in the nucleus. 
acetyltransferase (HAT) with STAT3 [29, 44]. Nie et al. confirmed that acetylation of the C-terminal lysine 679, 685, 707, and 709 lysine sites are associated with STAT3 phosphorylation, which is not affected by acetylation of the N-terminal 49 and 87 lysine sites [45]. Site-mutagenesis of the four C-terminal acetylation sites of STAT3 together inhibits STAT3 phosphorylation at site tyrosine 705, and the nuclear localization and transcriptional activity of STAT3 are also suppressed [45]. Thus, phosphorylation of STAT3 at site tyrosine 705 requires C-terminal lysine acetylation.

\section{Phenotypes of STAT3 deletion mouse models}

STAT3 is required during embryonic development. Two STAT3 isoforms were generated by alternatively splicing, the full-length STAT3 $\alpha$ and the C-terminal activation domain truncated STAT3 $\beta$ with a shift from TTCSNTI to FIDAVWK, corresponding to amino acids 716-722 [46, 47]. Germline Stat $3 \alpha \beta$ deletion leads to embryonic degeneration and lethality after egg cylinder stage between E6.5 and E7.5 [48]. Deletion of Stat $3 \alpha$ does not cause embryonic lethality, but the newborn Stat $3 \alpha^{-/-}$ mice die afterbirth due to dyspnea. Mice lacking Stat $3 \beta$ survive to adulthood; however, they are hypersensitive to lipopolysaccharide (LPS) -induced inflammation. The expression of STAT3 $\beta$ rescues embryonic deaths caused by Stat $3 \alpha \beta$-null mutation $[49,50]$. STAT3 $\beta$ is not a dominant negative factor as it mediates the transcription of acute-phase genes in the liver [49].

To delete Stat3 gene in specific tissues or cells in vivo, the conditional knockout models of Stat3 have been generated and crossed with tissue specific Cre mice. Mice with conditional STAT3 deletions in ECs are healthy and fertile, but their mortality after LPS treatment is increased [51]. STAT3-deletion in cardiac ECs decreases STAT3 activity in cardiomyocytes, leading to a decreased recovery of myocardial function after ischemia/reperfusion (I/R). These affected cardiomyocytes showed higher levels of caspase- 8 activity, and underwent apoptosis after I/R $[52,53]$. At the same time, myocardial expressions of (Interleukin-6) IL-6 and suppressor of cytokine signal 3 (SOCS3) are increased after I/R, suggesting that STAT3-null cardiac ECs may not receive the pro-angiogenic signal released by cardiomyocytes. On the other hand, the deletion of STAT3 in cardiomyocytes inhibits EC proliferation [54], perhaps as a result of enhanced expression of anti-angiogenesis factors, such as tissue inhibitor of metalloproteinase 1, connective tissue growth factor, and thrombospondin-1 [55-58]. Therefore, both cardiomyocytes and ECs require STAT3 activation to promote cardiac angiogenesis, and STAT3 may mediate the crosstalk between cardiomyocytes and ECs. STAT3 also participates in hypoxia-induced angiogenesis. STAT3 ablation in mesenchymal stem cells (MSCs) neutralizes hypoxia-induced release of VEGF and inhibits angiogenesis after ischemia, which decreases the protective role of MSCs against myocardial ischemia [59]. STAT3 deficiency in the pancreas causes incomplete development of the pancreatic microvasculature, which may restrict insulin transportation, leading to glucose intolerance and a defect in insulin secretion in vivo [60]. Together, STAT3 deletion impairs tissue vasculature, and STAT3 promotes angiogenesis by regulating the phenotypes of both ECs and non-ECs.

\section{Mechanistic events of STAT3 signaling in tumor cells and ECs in angiogenesis}

STAT3 engages hypoxia-responsive gene transcription in tumor cells [61]. As shown in Figure 2A, hypoxia induces STAT3 activation and formation of transcriptional complexes that promotes the expression of VEGF in tumors. In pancreatic and prostate carcinomas, such complexes contain STAT3, HIF-1 $\alpha$, CREB-binding protein $(\mathrm{CBP} / \mathrm{p} 300)$, and redox effector factor-1/apurinic/ apyrimidinic endonuclease (Ref-1/APE) [62]. Similarly, in breast cancer cells and Hep3B hepatoma cells, complexes constituted by STAT3, CBP/p300, RNA polymerase II (Pol II), and HIF-1 $\alpha$ are reported to regulate HIF-1 $\alpha$ target genes including VEGF [63]. These STAT3-mediated gene expressions in cancer cells promote angiogenesis. VEGF expression correlates with STAT3 activity in diverse human cancer cell lines. In human cancer cell lines, an activated STAT3 mutant (STAT3C) increases VEGF expression by binding to $V E G F$ gene promoter [64]. Inhibiting JAK2 and STAT3 expression both suppressed STAT3 activation and reduced the expression of VEGF and bFGF in non-small-cell lung cancer (NSCLC) [65]. In addition, IL-6 promotes angiogenesis and cervical tumor growth by activating the STAT3-VEGF pathway [66]. Glycophosphatidyl inositol (GPI)-anchored folate receptor alpha (FRalpha) is up-regulated in many types of cancer cells. Folic acid and folinic acid activate STAT3 through the FRalpha/JAK/STAT3 pathway, promoting HeLa cell proliferation through the expression of STAT3 target genes including Cyclin A2 and VEGF [67]. MMP2, MMP9 are also secreted by cancer cells in a STAT3-dependant manner $[68,69]$. In addition to direct activation of STAT3, other mechanisms promoting tumor angiogenesis are facilitated by STAT3. For instance, reversion-inducing cysteine-rich protein with kazal motifs (RECK) inhibits STAT3 activity by binding with $\beta 1$-integrin, IL-6RA, glycoprotein 130 (gp130), and urokinase receptor (UPAR) in the membrane, resulting in remarkable STAT3 inhibition in breast cancer cells. The inhibition of RECK, however, promotes angiogenesis and metastasis of breast cancer [70]. Recent research has found that cigarette smoke extract activates STAT3 in bronchial epithelial cells and promotes exosomal bubbling. The miR-21containing exosomes are endocytosed by ECs to modulate gene expression and facilitate vascular formation [71]. 
The miR-9 is secreted by tumor cells, and activates STAT3 in ECs by inhibiting SOCS5 levels, leading to migration of ECs and tumor angiogenesis [72]. These studies demonstrate that the activation of STAT3 in tumor cells establishes a microenvironment that is conducive to angiogenesis by mediating the secretion of pro-angiogenic factors.

The intercellular communication between tumors and ECs is facilitated by STAT3 [73]. ECs are the primary targets of VEGF signal produced by other cells, especially by cancer cells [74]. STAT3 activation mediates VEGFinduced EC migration and tube formation $[75,76]$. The IL-6/IL-6R/STAT3 axis is another important pathway for angiogenesis. It is well established that IL-6 activates STAT3 through IL-6Ralpha and gp130 [77]. The L1 transmembrane glycoprotein (also known as L1CAM or CD171) induces STAT3 activity via the IL-6/IL-6RA axis, and promotes cell proliferation, migration, tubulogenesis and vascular permeability in lung ECs [78]. In ECs, STAT3 requires co-factors to promote gene expression. It is reported that HIF-1 $\alpha$, STAT3, and specificity protein 1 (Sp1) can increase VEGF expression in mouse cerebral endothelial cells. To date it is not clear whether these three factors directly interact each other. However, the results of ChIP-PCR showed that the binding site of HIF-1 $\alpha$ (-931 to -912$)$ and STAT3 (-805 to -786$)$ are very close, and the Sp1 binding site ( -89 to -65$)$ is at the 3 ' side. Considering the spatial structure of proteins and DNA, it is possible that these proteins may form a complex and regulate gene expression together [79].

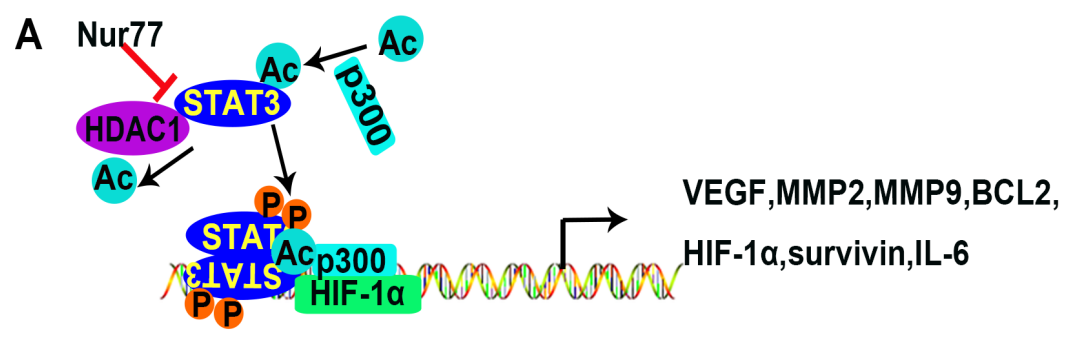

B

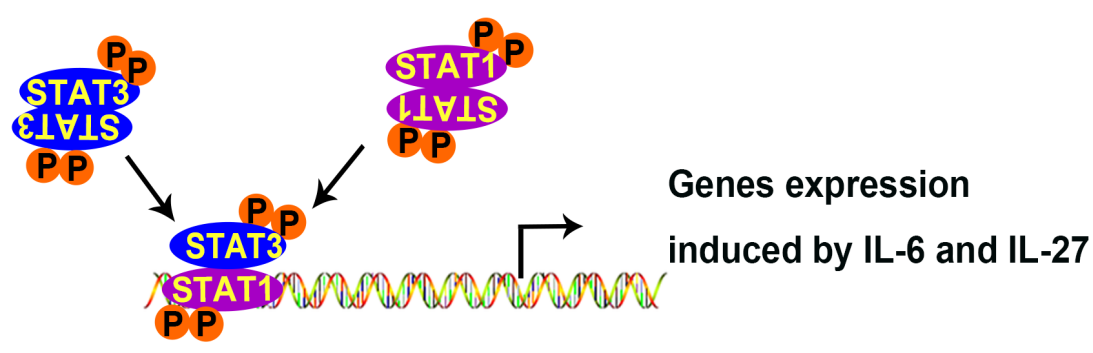

C

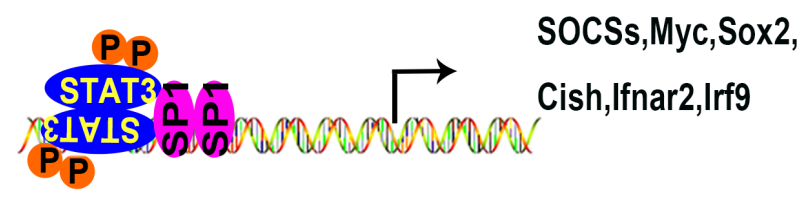

D

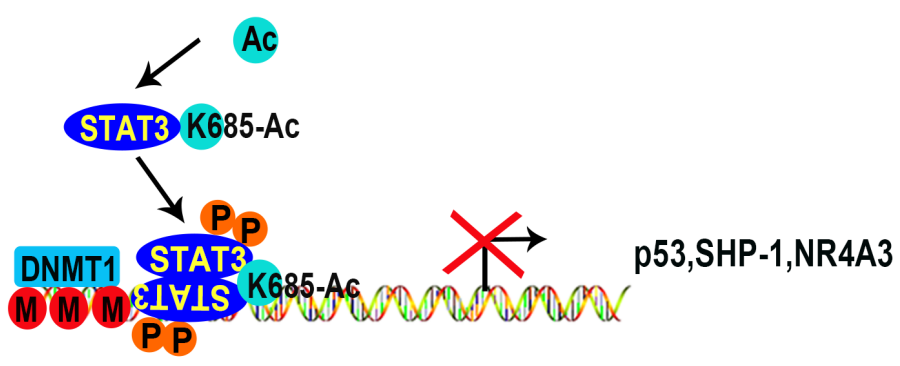

P Phosphorylation M Methylation AC Acetylation

Figure 2: Mechanisms of transcriptional activation or inhibition of target genes by STAT3. (A) STAT3 dimers activate gene expression with co-factors p300 and HIF-1 $\alpha$. (B) STAT3 is activated by IL-6 and IL-27 in T cells. STAT3 homodimers or heterodimers are translocated into the nucleus and bind to special DNA sequences, initiating gene transcription. (C) STAT3 interacts with co-factors such as STAT1 or SP1 to promote gene expression in stem cells. (D) STAT3 dimers inhibit gene expression by recruiting the DNA methyltransferase DNMT1. (Ac, acetylation; M, methylation; P, phosphorylation; DNMT1, DNA (cytosine-5)-methyltransferase 1; HDAC1, histone deacetylase 1; HIF-1 $\alpha$, hypoxia-inducible factors 1alpha; MMP2, metalloprotease 2; Nur77, nerve growth factor-induced gene B; SHP-1, Src homology region 2 domain-containing phosphatase 1; SP1, specificity protein 1). 
STAT3 also mediates pro-angiogenic signaling events in other cell types. For example, activation of STAT3 can be observed in VSMCs, macrophages, dendritic cells, bone marrow stem cells, and fibroblasts. STAT3 mediates the expression of a large number of genes upon different stimulations in multiple cell types (Table 1). Expression of these downstream genes may be antiapoptotic or control the cell cycle, cell adhesion or cell migration, thus contributing to angiogenesis [70, 80-99].

\section{Other potential mechanisms of STAT3-regulated angiogenesis}

A genome-wide ChIP-assay in macrophages and $\mathrm{T}$ cells found that STAT3 binding sites are widely distributed $[100,101]$. STAT family members collaborate to regulate transcription. For example, STAT1 often binds to chromatin in a STAT3 dependent manner (Figure 2B). However, in T cell-mediated anti-tumor immunity, STAT3 activation inhibits immune responses by antagonizing NF$\kappa \mathrm{B}$ and STAT1-mediated expression of T helper 1 (Th1) cytokines [102, 103]. Although the antagonizing effect of STAT3 to STAT1 has been well documented [104], this effect has not been examined in ECs.

STAT3 requires co-factors such as $\mathrm{Sp} 1$ to promote gene expression [105] (Figure 2C). In addition, STAT3 can be acetylated due to interaction with $\mathrm{CBP} / \mathrm{p} 300[62$, $63,91,106]$. Wu et al. demonstrated that nerve growth factor-induced gene B (NGFI-B or Nur77) promotes the acetylation of STAT3 by p300 while preventing the interaction between STAT3 and histone deacetylase 1 (HDAC1). Consequently, Nur77 is conducive to the expression of STAT3 target genes in the hypothalamus [107]. This suggests that STAT3 complex formation requires additional co-factors. The effect of Nur77 on STAT3 has not been reported in either cancer cells or ECs. Nur77 is involved in VEGF-A-induced angiogenesis [108], vascular hyperpermeability [109], and upregulation of integrin $\beta 4$ expression in HUVECs [110]. Together, we speculate that Nur77 promotes angiogenesis by maintaining STAT3 activation.

STAT3 also inhibits transcription of a variety of genes. This is associated with DNA methylation as shown in Figure 2D. Acetylation of STAT3 at K685 is needed for its interaction with DNA (cytosine-5)-methyltransferase 1 (DNMT1) [94, 111]. SH-I-14 and resveratrol inhibit the acetylation of STAT3 (K685) and disrupt the interaction between STAT3 and DNMT1, which leads to de-methylation of tumor suppressor genes promoter regions in triple-negative breast cancer (TNBC) [94, 112]. STAT3 has been reported to repress tumor suppressor gene expression by binding to promoter regions of $p 53$, Src homology region2 domain-containing phosphatase-1 (SHP-1), and Nr4a3 [96, 113, 114]. In tumor cells, p53 inhibits tumor angiogenesis under hypoxia conditions by promoting HIF-1 $\alpha$ degradation and decreasing VEGF expression [115]. Mutations of p53 at R175H, R273H, and $\mathrm{R} 280 \mathrm{~K}$ promote tumor angiogenesis [116]. SHP-1 is a key negative regulator of STAT3. In conjunction with DNMT1, STAT3 inhibits SHP-1 transcription by methylating the promoter region in T cell lymphomas [96]. Little is known about STAT3 associated epigenetic modification, and this needs further investigation regarding the mechanisms of STAT3-mediated angiogenesis.

In addition to interacting with transcriptional cofactors, STAT3 has been reported to bind with many other proteins that may either promote or inhibit its activation. We utilized STITCH (http://stitch.embl.de/) to analyze proteins that interact with STAT3. Figure 3 shows the interaction networks of these proteins and also predicts their possible effects. Understanding the role of these interactions in angiogenesis will help shed light on the regulatory mechanism of STAT3.

\section{STAT3 in hypoxia-induced angiogenesis}

Hypoxia is a common feature of cancer. It initiates a variety of cellular responses including activation of STAT3 and promotes expression of VEGF [64, 117]. The most crucial transcription factor activated under hypoxic conditions is HIF-1, which promotes hypoxiainducible gene products, such as VEGF. HIF-1 contains two subunits, HIF- $1 \alpha$ and HIF-1 $\beta$. In normoxia condition, the expression of HIF-1 $\beta$ is sustained while HIF- $1 \alpha$ is degredated in a HIF prolyl hydroxylases (PHDs) dependent manner. In hypoxia condition, the interaction of PHDs and HIF-1 $\alpha$ is inhibited thus HIF- $1 \alpha$ stability is maintained [118]. STAT3 and HIF-1 $\alpha$ increase the expression of VEGF thus promote tumor angiogenesis. Figure 4 is a conceptual diagram that shows roles of STAT3 in hypoxia-induced angiogenesis in cancer cells and ECs.

During hypoxia, STAT3 and HIF-1 $\alpha$ cooperatively activate HIF-1 $\alpha$ target genes, VEGF, phosphoglycerate kinase 1 (PGK1), and carbonic anhydrase 9 (CA9) in prostate cancer cells [117]. As discussed before, the coactivators $\mathrm{CBP} / \mathrm{p} 300$ and $\mathrm{Ref}-1 / \mathrm{APE}$ are required to promote the target genes expression. In cancer cells, the complexes containing STAT3, HIF-1 $\alpha, \mathrm{CBP} / \mathrm{p} 300$, and Ref-1/APE bind to the Vegf promoter and increase VEGF expression [62]. In addition, STAT3 is required for both basal and induced expression of HIF-1 $\alpha$, and inhibits HIF$1 \alpha$ degradation [119]. Inhibition of STAT3 with a smallmolecule inhibitor blocks HIF-1 $\alpha$ and VEGF expression in vitro $[85]$.

At hypoxia condition, ROS mediates STAT3 activation [120]. Nicotinamide adenine dinucleotide phosphate oxidase 4 (Nox4) is a major route of ROS production. Nox4 expression is up-regulated under hypoxia condition. Both Nox4 siRNA and ROS inhibitors decrease hypoxia-induced STAT3 activation. In addition, the conditioned medium from Nox4 knock-down tumor 
Table 1: STAT3 regulated genes

\begin{tabular}{|c|c|c|c|}
\hline Cell types & Target genes & Functions & References \\
\hline Cancer cells & $\begin{array}{l}\text { NR4A3, Forkhead BoxM1(FoxM1), } \\
\text { MUC4, CDX2, Cyclin D1, Cyclin A2, } \\
\text { AHSP, Bcl-2, survivin, VEGF, PGK1, } \\
\text { CA9, MMP2, MMP9, CDX2, PD-L1, } \\
\text { miR155-3p, miR-146a, p53 }\end{array}$ & $\begin{array}{l}\text { proliferation, survival, } \\
\text { migration, angiogenesis, anti- } \\
\text { tumor immune suppression }\end{array}$ & $\begin{array}{c}{[70,80,82-86,89-91} \\
93,96,98,99]\end{array}$ \\
\hline ECs & $\begin{array}{c}\text { Cyclin D1, Bcl-3, bFGF, VEGF-C, } \\
\text { HIF-1 } \alpha \text {, miR-21, c-jun, eNOS, ICAM- } \\
\text { 1, NOSTRIN }\end{array}$ & $\begin{array}{l}\text { proliferation, survival, } \\
\text { migration, angiogenesis }\end{array}$ & $\begin{array}{c}{[71,80,82,85,88,92,} \\
97,123]\end{array}$ \\
\hline Stem cells & $\begin{array}{c}\text { Stat1, Socs2, Socs3, Cish, Ifnar2, Irf9, } \\
\text { Alkaline phosphatase (ALP), Myc, } \\
\text { Sox2 }\end{array}$ & $\begin{array}{l}\text { differentiation, migration, } \\
\text { self renewal }\end{array}$ & {$[62,84,95]$} \\
\hline Other cells & $\begin{array}{l}\text { Bfgf, Pax, Igf2bp2, Hmga1, TIMP1, } \\
\text { siR-199a, SHP-1 }\end{array}$ & $\begin{array}{l}\text { migration, angiogenesis, } \\
\text { inflammation }\end{array}$ & {$[81,88,113,121,193]$} \\
\hline
\end{tabular}

cells fails to induce tube formation of ECs in vitro [121]. In addition to ROS, several proteins affect STAT3 activity under hypoxia. By inhibiting STAT3, RNA-dependent protein kinase R (PKR), an eukaryotic initiation factor 2alpha (eIF2 $\alpha$ ) kinase, decreases HIF-1 $\alpha$ and VEGF expression in cancer cells [122]. Mammalian target of rapamycin complex 1 (mTORC1) activates STAT3 during hypoxia in renal cystadenoma cells, and promotes HIF-1 $\alpha$ and VEGF expression [123]. Together, STAT3 activation is crucial for HIF-1 $\alpha$ and VEGF expression in cancer cells under hypoxia.

Activation of STAT3 is also detected in ECs in response to abnormal oxygen supply. Hypoxia promotes human retinal microvascular endothelial cells (HRMVECs) migration, sprouting, and tube formation, mediated by increased expression of c-Jun via the prolinerich tyrosine kinase 2 (Pyk2)/STAT3 signaling pathway [124]. Hypoxia also up-regulates the transcriptional production of platelet-derived growth factor-B (PDGF-B) in ECs, resulting in STAT3 activation and the inhibition of EC apoptosis in an autocrine manner. Additionally, PDGF-B activates phosphatidylinositol 3-kinase (PI3K)/ protein kinase B (AKT) pathway, the upstream of STAT3 activation [125]. Activation of STAT3 maintains the viability of hypoxia-treated endothelial colony-forming cells (ECFCs). Hypoxia activates STAT3 and increases the expression of a downstream gene, B-cell lymphoma 3 -encoded protein (BCL-3) [126]. These results demonstrate that hypoxia activate STAT3 in distinct pathways in different cell types. No matter how the activation is initiated, the STAT3/HIF-1 $\alpha$ pathway under hypoxic condition promotes angiogenesis.

\section{STAT3 in inflammation-induced angiogenesis}

Chronic inflammation markedly increases the risk of cancer [127]. It generates an inflammatory microenvironment to facilitate angiogenesis and support tumor progression [128]. An inflammatory microenvironment is characterized by the presence of specific inflammatory cells and inflammatory mediators [129]. Several studies suggest that STAT3 transmits inflammatory signals [98, 130-134]. Pro-inflammatory factors may activate STAT3 in both tumor cells and ECs to induce angiogenesis (Figure 5).

IL-6, a pleiotropic inflammatory cytokine, is a marker of chronic inflammation [135]. Many lines of evidence demonstrate that IL-6 promotes tumor progression in multiple ways [136-138], including enhanced angiogenesis [139] and lymphangiogenesis [140]. EC-derived IL-6 induces phosphorylation of STAT3 in tumor cells [141] and promotes tumor growth [142]. IL-6 treatment activates the gp130/STAT3 pathway in gastric cancer cells to up-regulate MUC4, which can be detected at early stages of the gastric carcinogenetic process. STAT3 binds to Muc4 promoter at -123 to -115 and up-regulates its transcription [143, 144]. In basal cell carcinoma, IL-6 induces bFGF expression via the JAK/STAT3 pathway, promoting angiogenesis [145]. Competitive inhibition STAT3 with a dominantnegative mutant protein blocks IL-6-induced VEGF mRNA expression, and thus prevents VEGF-mediated angiogenesis and tumorigenesis. In contrast, inhibition of MAPK and PI3K in cervical cancer cells does not affect VEGF expression [146]. IL-6 also activates STAT3 in non-tumor cells. In murine lymphatic ECs, IL-6 induces VEGF expression via the Src-FAK-STAT3 pathway and increases lymphangiogenesis [147]. In chronic subdural hematoma (CSDH), an angiogenic and inflammatory disease which has an increased level of IL-6 in hematoma fluid, was found to activate STAT3 in ECs. This suggests that IL-6 enhances the JAK/STAT3 signaling pathway to promote $\mathrm{EC}$ proliferation and angiogenesis in CSDH outer membranes [148]. Moreover, human mesothelial cells in the peritoneal cavity of peritoneal dialysis (PD) patients have higher VEGF production due to IL-6-induced 


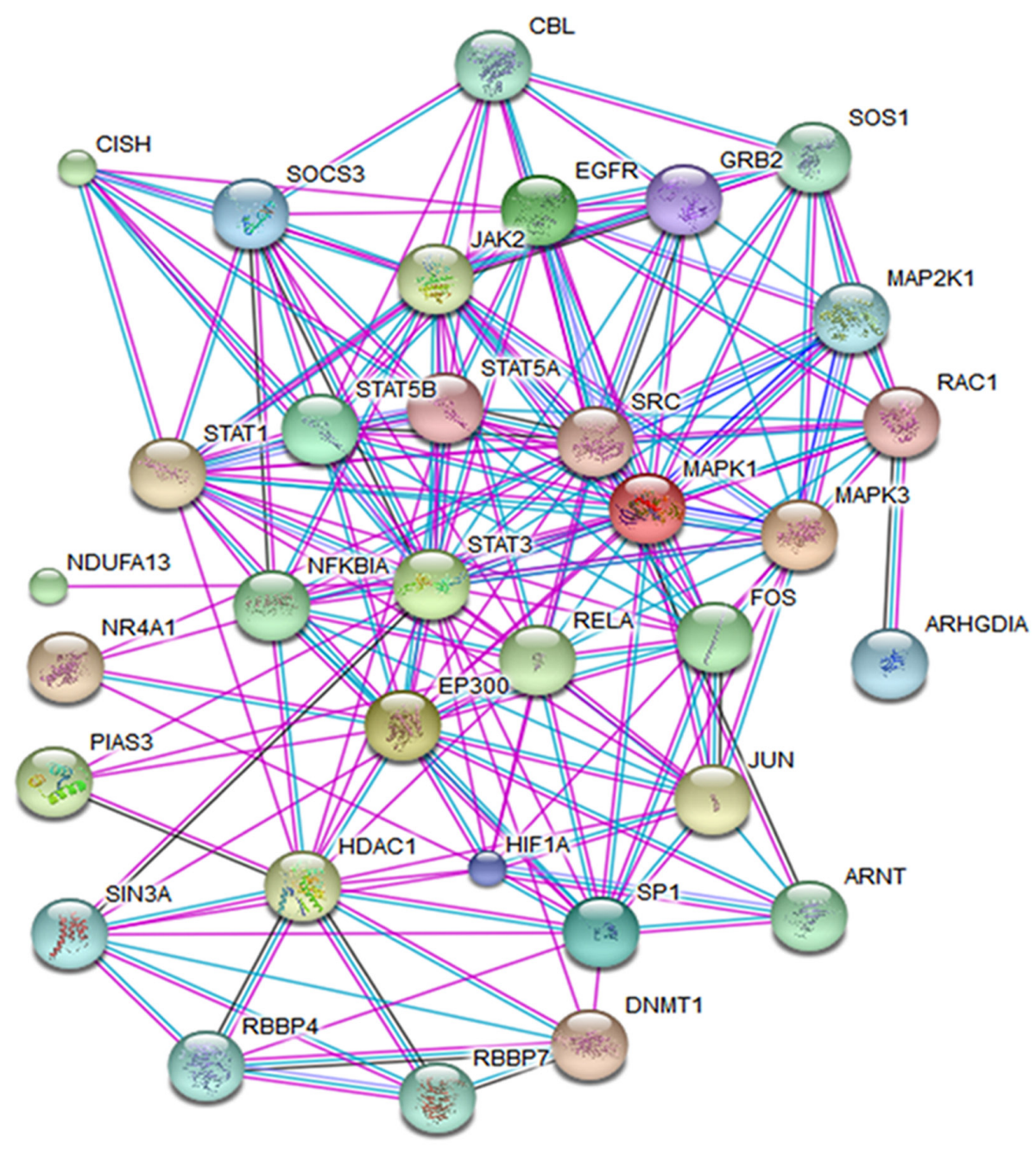

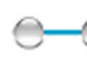

From curated database

\section{Experimentally determined}

Textmining

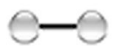

Co-expression
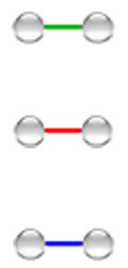

e-e

\section{Gene neighborhood}

\section{Gene fusions}

\section{Gene co-occurrence}

Protein homology

Figure 3: Interactions between STAT3 and other proteins. This figure is generated using the website STITCH (http://stitch.embl. $\mathrm{de} /$ ). The proteins were submitted to the human database. The interactions provided by the database are based on the eight aspects: known interactions encompassing results from curated databases, experimentally determined and predicted interactions gene neighborhood, gene fusions, and gene co-occurrence, textmining, co-expression, and protein homology. Only the proteins relevant to tumor angiogenesis and directly interplaying with STAT3 are shown. (ARNT, aryl hydrocarbon receptor nuclear translocator; CBL, Cbl proto-oncogene, E3 ubiquitin protein ligase; CISH, cytokine inducible SH2-containing protein; C-JUN, jun proto-oncogene; DNMT1, DNA (cytosine-5)methyltransferase 1; EGFR, epidermal growth factor receptor; EP300, E1A binding protein p300; GRB2, growth factor receptor-bound protein 2; HIF-1 $\alpha$, hypoxia-inducible factor 1 subunit $\alpha$; HDAC1, histone deacetylase 1; JAK, Janus kinase; MAPK1/3, mitogen-activated protein kinase 1/3; MAP2K1, mitogen-activated protein kinase kinase 1; NDUFA13, NADH dehydrogenase (ubiquinone) 1 alpha subcomplex 13; NIK, NF-кB-inducing kinase; NR4A1, nerve growth factor-induced gene B; PI3K, phosphatidylinositol 3-kinase; PIAS3, protein inhibitor of activated STAT3; RAC1, Ras-related C3 botulinum toxin substrate 1; RBBP4/7, retinoblastoma binding protein 4/7; RELA, v-relreticuloendotheliosis viral oncogene homolog A; SIN3A, SIN3 transcription regulator homolog A; SOCS, suppressors of cytokinesignaling; SOS1, son of sevenless homolog 1; STAT1/3/5A/5B, signal transducers and activators of transcription 1/3/5A/5B; SP1, specificity protein 1; SRC, v-src sarcoma (Schmidt-Ruppin A-2) viral oncogene homolog). 
activation of STAT3 [149]. These results demonstrate that IL-6 promotes angiogenesis in STAT3-dependent manner by inducing VEGF expression in both tumor and nontumor cells.

IL-17 increases IL-6 expression through the AKT pathway in hepatocellular carcinoma (HCC). The IL-17induced IL-6 activates STAT3 and increases the expression of pro-angiogenic factors such as IL-8, MMP2, and VEGF to promote angiogenesis and tumor growth in vivo [150]. In both B16 melanoma and MB49 bladder carcinoma, IL-17-induced IL-6 production is mediated by STAT3 activation [151]. The increase of VEGF expression has also been detected in gastric cancer, which is stimulated by IL-17 in a STAT3 dependent manner [152]. Hou, et al. reported that IL-17 directly promotes human endothelial cells (HECs) activation and neutrophil recruitment by activating STAT3, thus up-regulating its downstream targets such as C-X-C motif chemokine ligand 1 (CXCL1 or GRO- $\alpha$ ), granulocyte-macrophage colony stimulating factor (GM-CSF) and IL-8 [153].

Under conditions such as myocardial infarction (MI) and hypoxia, anti-inflammatory cytokines also promote angiogenesis via the STAT3 signaling pathway. IL-10 is a potent anti-inflammatory cytokine. Its effect on angiogenesis has been well documented [154-158]. IL10 increases vascular density and improves ventricular function by activating STAT3 and increasing VEGF expression in the myocardium after MI [159]. Deletion of IL-10 impairs MI-induced endothelial progenitor cell (EPC) mobilization in mouse MI models. In vitro, IL-10 treatment increases EPC survival and augments EPCmediated neo-vascularization via the activation of STAT3/ VEGF signaling cascades [160]. IL-10 also activates STAT3 signaling in macrophages [161], and promotes pathological retinal angiogenesis by increasing VEGF expression under hypoxia [162]. Other studies of AMD patients suggest that IL-10 induces alternative activation of macrophages and vascular proliferation via the STAT3 signaling pathway, presumably by impairing SOCS3 feedback in senescent macrophages [163]. Other IL-10 family cytokines including IL-19 and IL-22 also facilitate angiogenesis in a STAT3-dependent manner [164, 165]. IL-19 promotes angiogenesis directly by activating STAT3 in vascular cells and indirectly by activating macrophages STAT3 to release pro-angiogenic factors [166]. Leukocytes secrete IL-22, which activates STAT3 in HCC and up-regulate VEGF expression [167]. Taken together, pro-inflammatory factors and anti-inflammatory

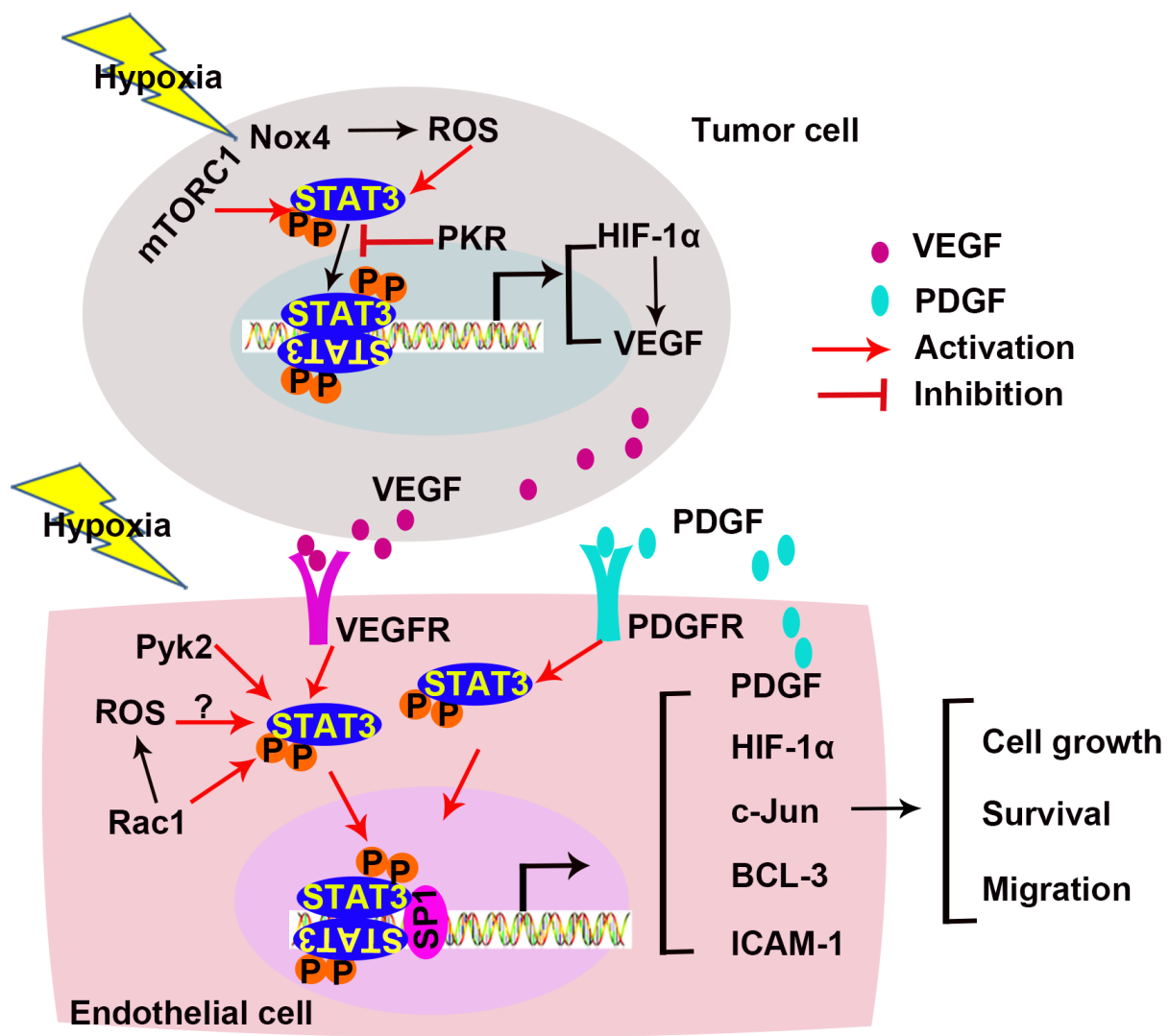

Figure 4: STAT3 in hypoxia-induced angiogenesis. Hypoxia activates STAT3 in both tumor cells and ECs. Under hypoxic conditions, the STAT3/HIF-1 $\alpha$ pathway promotes angiogenesis. Crosstalks between ECs and cancer cells also involve in angiogenesis. (ICAM-1, intercellular cell adhesion molecule-1; mTORC1, mammalian target of rapamycin complex 1; Nox4, nicotinamide adenine dinucleotide phosphate oxidase 4; PDGF-B, Platelet-derived growth factor-B; PKR, RNA-dependent protein kinase R; Pyk2, proline-rich tyrosine kinase 2; ROS, reactive oxygen species; Sp1, specificity protein 1). 
factors both activate the STAT3 pathway. However, the target cells of these cytokines vary across different diseases. Intriguingly, STAT3 activation always promotes angiogenesis, regardless of the variations in upstream signaling events.

\section{STAT3 as a therapeutic target}

Inhibition of the STAT3 signaling is a potential therapeutic strategy for tumor and other angiogenesis related diseases $[10,19]$. As shown in Tables 2 and 3 [85, 156, 159, 161-189], which summarize articles published since 2013, numerous natural and synthetic molecules are known to inhibit the components of the STAT3 signaling and related signaling pathways. The STAT3 molecules and pathways that are targeted by various inhibitors are illustrated in Figure 6.

Both natural materials and synthetic small molecules were developed to inhibit STAT3. Along with the increased understanding of microRNAs, a number of non-coding
RNAs have been found to modulate the STAT3 signaling pathway. The most common inhibitors are designed to directly inhibit STAT3 expression and activation. For example, both tanshinone I and acacetin are natural materials that inhibit STAT3 activation by preventing STAT3 705 Tyr-phosphorylation in ECs and cancer cells. Treatment with these molecules down-regulates VEGF expression and attenuates vascular formation [85]. Astaxanthin, a non-provitamin A carotenoid with potent anti-oxidant effects, is predominantly found in microalgae, fungi, and plants [171]. Astaxanthin blocks STAT3 activity by forming hydrogen bond with Met 1428, Glu 1523, Arg 1593, and Asn 538 on STAT3 in tumor cells, abrogating cell proliferation, invasion, and angiogenesis [170]. Wogonin, a natural flavonoid [172], directly prevents the phosphorylation of STAT3 on tyrosine 705 . Another natural product, scoparone, inhibits STAT3 by blocking its nuclear translocation and down-regulates MMP9, cyclinD, and survivin expression in VSMCs, which inhibits vascular remodeling [169]. In addition

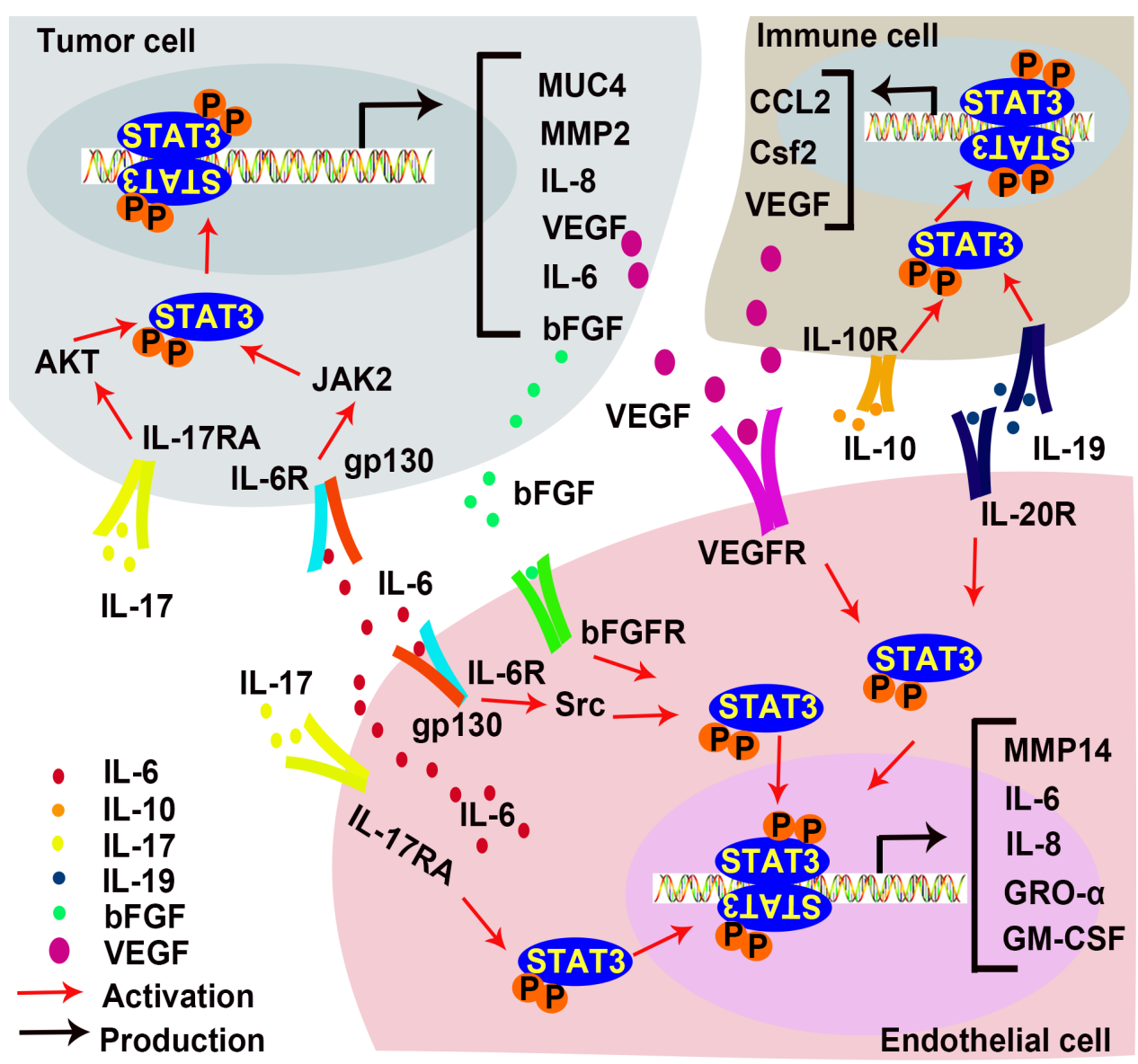

Figure 5: STAT3 in inflammation-induced angiogenesis. IL-17 promotes IL-6 production in EC and tumor cells, and directly interact with ECs to promote angiogenesis. IL-6 activates STAT3 in tumor cells and ECs to increase expressions of bFGF and VEGF. IL-10 activates STAT3 in inflammatory cells, resulting in the up-regulation of VEGF. IL-19 promotes angiogenesis directly by activating STAT3 in EC and indirectly by stimulating macrophage-released pro-angiogenic factors. (AKT, Protein kinase B; bFGF, basic fibroblast growth factor; GM-CSF, Granulocyte-macrophage colony-stimulating factor; GRO- $\alpha$ also known as CXCL1, C-X-C motif chemokine ligand 1; IL-6, Interleukin 6; IL-10, Interleukin 10; IL-17, Interleukin 17; IL-19, Interleukin 19; JAK, Janus kinases; MMP2, metalloprotease 2; MMP14, metalloprotease 14; MUC 4, Mucin 4; VEGF, vascular endothelial growth factor). 
Table 2: Inhibitors of STAT3 in development and angiogenesis

\begin{tabular}{|c|c|c|c|}
\hline Inhibitors & Cell/Tissues & Mechanisms & References \\
\hline \multicolumn{4}{|l|}{ Natural } \\
\hline Scoparone & VSMC & $\begin{array}{l}\text { Blocks the transportation of STAT3 from the } \\
\text { cytosol to the nucleus }\end{array}$ & [169] \\
\hline Indoxyl sulfate & Mouse EPCs/ human EPCs & Unclear & [182] \\
\hline adiponectin & Human VSM and VECs & Induces SOCS to inhibit STAT3 & [184] \\
\hline melatonin & HepG2/ HeLa/ HUVECs & Unclear & [186] \\
\hline Tanshinone I & $\begin{array}{l}\text { Vascular endothelial cells/ } \\
\text { tumor }\end{array}$ & Inhibits STAT3 705 Tyr-phosphorylation & [85] \\
\hline Indirubin & $\begin{array}{l}\text { Human endothelial cells/ } \\
\text { tumor }\end{array}$ & Inhibits VEGFR/JAK2/ STAT3 phosphorylation & [178] \\
\hline Wogonin & Tumor/ HUVECs & $\begin{array}{l}\text { Inhibits STAT3 } 705 \text { Tyr-phosphorylation and } \\
\text { promotes dephosphorylation }\end{array}$ & [172] \\
\hline Astaxanthin & Tumor & Inhibit STAT3 phosphorylation & {$[170]$} \\
\hline GYY4137 & $\begin{array}{l}\text { Human hepatocellular } \\
\text { carcinoma (HCC) }\end{array}$ & Inhibits JAK2/STAT3 & [195] \\
\hline Icaritin & Renal cell carcinoma & $\begin{array}{l}\text { Inhibits IL-6-induced STAT3 } 705 \text { Tyr- } \\
\text { phosphorylation }\end{array}$ & [191] \\
\hline Butein & $\begin{array}{l}\text { Human Multiple Myeloma/ } \\
\text { tumor }\end{array}$ & $\begin{array}{l}\text { Induces SHP-1 to dephosphorylate JAK2 and } \\
\text { STAT3 }\end{array}$ & [199] \\
\hline resveratrol & Tumor & Induces GRIM19 to inhibit STAT3 & [203] \\
\hline Acacetin & HUVECs/ tumor & Inhibits STAT3 705 Tyr-phosphorylation & [187] \\
\hline$\alpha$-Solanine & Tumor & Unclear & [205] \\
\hline $\begin{array}{l}\text { JSI-124 } \\
\text { (Cucurbitacin I) }\end{array}$ & Tumor & Unclear & [183] \\
\hline \multicolumn{4}{|l|}{ Synthetic } \\
\hline TEL03 & Tumor & $\begin{array}{l}\text { Inhibits STAT3 phosphorylation by interacting } \\
\text { with SH2 domain }\end{array}$ & [190] \\
\hline LCB03-0110 & $\begin{array}{l}\text { Human endothelial cells/ } \\
\text { tumor }\end{array}$ & $\begin{array}{l}\text { Targets VEGFR-2 kinase activity by binding to } \\
\text { the ATP-binding site }\end{array}$ & [177] \\
\hline P3971 & Tumor & Unclear & [185] \\
\hline
\end{tabular}

to natural materials, TEL03, a perylene derivative, is a dual inhibitor that targets both HIF-1 $\alpha$ and STAT3 [190]. Surface plasmon resonance shows that TEL03 interacts with the residues of E612, S613, and E638 in SH2 domain of STAT3; therefore it disrupts the interaction between STAT3 and the phosphotyrosine-stimulating receptor. Icaritin, a hydrolytic product of icarin from a traditional Chinese herbal medicine (genus pimedium), restricts renal tumor growth by inhibiting STAT3 activity and VEGF expression in vivo [191]. As shown in Table 3, there are many microRNAs which reduce STAT3 expression by targeting STAT3 mRNA and impair tumor vascular formation. 27-nt from the eNOS 4th intron is an intronic microRNA which inhibits STAT3 expression in human aortic endothelial cells (HAECs) [175]. Other microRNAs such as microRNA-124 [173, 174, 192], microRNA-351 [193], and microRNA-146a [176] are also
STAT3 inhibitors. Instead of binding to STAT3 mRNA, microRNA-9600 directly binds to STAT3 protein and promotes STAT3 degradation in NSCLC [194].

Inhibitors might also target components of the signaling pathway upstream of STAT3. LCB03-0110, a thienopyridine derivative, inhibits VEGFR-2 and c-Src kinase activity via preferential binding to the ATP-binding site. Consequently, STAT3 activation in ECs is inhibited, and angiogenesis is reduced [177]. Indirubin, an active constituent of banlangen [179], inhibits angiogenesis by blocking VEGFR2 phosphorylation on Tyr996 and Tyr1175, and inhibiting JAK/STAT3 signaling in ECs [178]. GYY4137, a hydrogen sulfide $\left(\mathrm{H}_{2} \mathrm{~S}\right)$ donor, suppresses STAT3 activation by effectively reducing p-STAT3 levels in cancer cells. GYY4137 treatment leads to apoptosis and reduced release of angiogenesis factors in HepG2 cells [195]. MicroRNAs also block 
Table 3: Inhibitory microRNAs for STAT3 in tumor development and angiogenesis

\begin{tabular}{|c|c|c|c|}
\hline MicroRNAs & Tissues/ Cells & Mechanisms & References \\
\hline $\begin{array}{l}\text { 27-nt from eNOS4th intron/ } \\
\text { Intronic microRNA }\end{array}$ & $\begin{array}{l}\text { Human aortic endothelial cells } \\
\text { (HAECs) }\end{array}$ & $\begin{array}{l}\text { Inhibits eNOS and STAT3 } \\
\text { expression }\end{array}$ & {$[175]$} \\
\hline $\begin{array}{l}\text { microRNA-124/ ( let- } 7 \text {, miR- } \\
\text { 125, miR-26, or miR-101) }\end{array}$ & Ulcerative colitis/ tumor & $\begin{array}{l}\text { Binds to STAT3 3' UTR and } \\
\text { reduces STAT3 expression }\end{array}$ & {$[174,192]$} \\
\hline MicroRNA-101 & $\begin{array}{l}\text { Pulmonary microvascular } \\
\text { endothelial cells (PMVECs) }\end{array}$ & Targets JAK2 & [197] \\
\hline Mmu-microRNA-351 & Mouse endothelial cells & Targets STAT3 & [193] \\
\hline MicroRNA-9600 & $\begin{array}{l}\text { Tumor/ Non-small-cell lung cancer } \\
\text { (NSCLC) }\end{array}$ & $\begin{array}{l}\text { Directly binds STAT3 and } \\
\text { promotes degradation }\end{array}$ & [194] \\
\hline MicroRNA-451 & Hepatocellular carcinoma & Inhibits IL-6R & [196] \\
\hline MicroRNA-539 & Hepatocellular carcinoma & Unclear & [206] \\
\hline MicroRNA-146a & $\begin{array}{l}\text { Human cervical and colorectal } \\
\text { cancer }\end{array}$ & Inhibits STAT3 expression & [86] \\
\hline $\begin{array}{l}\text { MicroRNA-133b and } \\
\text { MicroRNA-135a }\end{array}$ & Human renal carcinoma & Unclear & {$[180]$} \\
\hline MicroRNA-148a & Human gastric cancer & $\begin{array}{l}\text { Inhibits cholecystokinin B receptor } \\
\text { (CCK-BR) }\end{array}$ & [181] \\
\hline
\end{tabular}

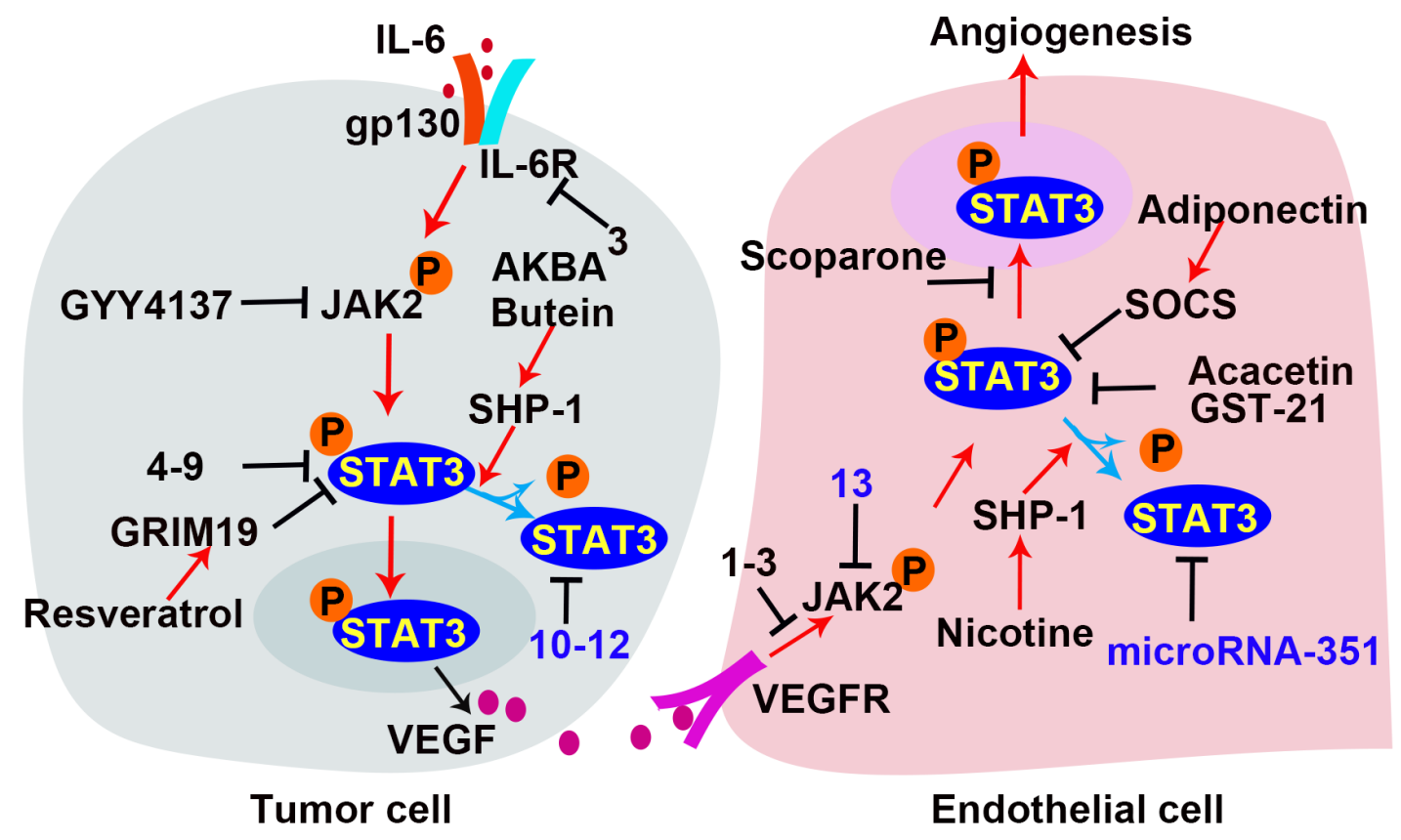

\section{1:LCB03-0110 2:Indirubin 3:microRNA-451 4:Acacetin 5:Icaritin 6:Astaxanthin 7:Tanshinone I 8:Wogonin 9:TEL03 10:microRNA-124 11:microRNA-146a 12:microRNA-9600 13:microRNA-101}

Figure 6: Inhibitors of the STAT3 signaling in tumor angiogenesis. In the process of tumor angiogenesis, the rapid proliferation of tumor cells leads to local hypoxia and inflammation, which activate STAT3 in tumor cells to produce pro-angiogenic factor. VEGF is a potent pro-angiogenic factor to promote EC angiogenesis. The VEGF/VEGFR signal activates STAT3 which subsequently promotes endothelial cell proliferation and migration by regulating the transcription of the targeted genes. Inhibition of STAT3 is a potential therapeutic strategy for tumor growth and angiogenesis. The established inhibitors are shown with the indication of black " $T$ " markers. 
STAT3 upstream signaling to inhibit STAT3 activation. MicroRNA-451 inhibits IL-6R transcription by targeting IL-6R 3' untranslated region (UTR), reducing IL-6R/ STAT3 signal and decreasing VEGF secretion in HCC [196]. MicroRNA-101 inhibits JAK2 transcription by targeting JAK2 3'UTR [197], and inhibits STAT3 activation in ECs to abrogate vascular formation.

SHP-1, SOCSs and protein inhibitor of activated STAT (PIAS3) are negative regulators of STAT3 and become the targets for suppression of STAT3 activity [198]. AKBA is a boswellic acid isolated from boswellia serrata, and butein has been isolated from numerous plants. Both AKBA and butein inhibit STAT3 via SHP1 in human multiple myeloma [199, 200]. Resveratrol is abundant in red grapes with no reported toxicity towards normal cells at effective anticancer doses [201]. PIAS3 is up-regulated by resveratrol treatment and inhibits STAT3 activation in cancer cells [202]. In addition to increasing PIAS3, resveratrol also up-regulates genes associated with retinoid-IFN-induced mortality 19 (GRIM19) to inhibit STAT3. Previous studies demonstrated that GRIM19 down-regulates p-STAT3 and that inhibiting GRIM19 with siRNAs restores cell proliferation induced by resveratrol [203, 204]. In addition, inhibitors such as $\alpha$-Solanine [205] and microRNA-539 [206] are demonstrated to be effective inhibitors of STAT3 activity and tumor growth. However, the mechanisms behind these effects remain to be investigated.

\section{CONCLUSIONS AND PROSPECTS}

Angiogenesis is required for tumor development, and inhibition of angiogenesis is a promising strategy for tumor treatment. Angiogenesis is a complex process that is mediated by multiple factors, among which STAT3 is one of the most prominent transcription factors. Hypoxia and inflammatory factors activate STAT3 to promote tumor angiogenesis. Persistent activation of STAT3 contributes to HIF-1 $\alpha$ and VEGF expression in cancer cells and other non-ECs. VEGF then activates STAT3 in ECs, and promotes cell proliferation, migration, and survival. In addition, STAT3 inhibits the expression of tumor suppressors, such as the anti-angiogenesis transcription factor $\mathrm{p} 53$.

Although many studies have demonstrated the positive role of STAT3 in promoting tumor angiogenesis, further research is needed to illuminate the detailed mechanisms of STAT3 in this process. For instance, it is worth noting that members of the STAT family are highly conserved, and STAT1, STAT5 and STAT6 also participate in vascular formation. Current studies focused on the effects of STAT3 homodimers in angiogenesis, but STAT3 might also form heterodimers with STAT1 or STAT5. The interactions between these STATs in regulating angiogenesis need to be furtherly investigated. Treatment strategies involving the inhibition of STAT3 activity have been investigated and specific agents are demonstrated to be effective. Nevertheless, treatments with single agent have not achieved an optimal effect due to the complexity of STAT3 regulation in vivo. The identification of more selective agents and combination use of the targeted inhibitors will be important challenges for development of therapeutic strategies.

\section{Abbreviations}

AKT, protein kinase B; AMD, age-related macular degeneration; BCL-3, B-cell lymphoma 3-encoded protein; Bcl-xL, B-cell lymphoma-extra large; bFGF, basic fibroblast growth factor; CA9, carbonic anhydrase 9; CRC, colorectal cancer; CBP/p300, CREB-binding protein; ChIP, Chromatin immunoprecipitation; CNS, central nervous system; CPCs, cardiac progenitor cells; $\mathrm{CSDH}$, chronic subdural hematoma; CXCL1 or GRO- $\alpha$, C-X-C motif chemokine ligand 1; CypD, cyclophilin D; DNMT1, DNA (cytosine-5)-methyltransferase 1; ECs, endothelial cells; ECFCs, endothelial colony-forming cells; ECM, extracellular matrix; eIF2 $\alpha$, eukaryotic initiation factor 2alpha; EGF, epidermal growth factor; EGFL7, epidermal growth factor (EGF)-like domain 7; EPC, endothelial progenitor cell; EPO, erythropoietin; ESCs, embryonic stem cells; ERK1/2, extracellular signalregulated kinase 1/2; EZH2, enhancer of zeste homolog 2; FAK, focal adhesion kinase; FRalpha, folate receptor alpha; GAS, interferon-gamma activated sequence; gp130, glycoprotein 130; GM-CSF, granulocyte-macrophage colony stimulating factor; GPI, Glycophosphatidyl inositol; GRIM19, genes associated with retinoid-IFN-induced mortality $19 ; \mathrm{H}_{2} \mathrm{~S}$, hydrogen sulfide; HAECs, human aortic endothelial cells; HAT, histone acetyltransferase; HCC, hepatocellular carcinoma; HDAC1, histone deacetylase 1; HECs, human endothelial cells; HIF-1 $\alpha$, hypoxia inducible factor lalpha; hPMSCs, Human placenta-derived multipotent mesenchymal stromal cells; HUVECs, human umbilical vein endothelial cells; HRMVECs, human retinal microvascular endothelial cells; IFN- $\alpha$, interferon- $\alpha$; IL- $1 \beta$, interleukin-1 $\beta$; IL-6, interlaukin-6; IL6R, IL-6 receptor; $\mathrm{I} / \mathrm{R}$, ischemia/reperfusion; JAK2, Janus kinases 2; KDa, kilo-dalton; L1CAM, L1 transmembrane glycoprotein; LPS, lipopolysaccharide; MAPK, mitogen-activated protein kinase; MEF, mouse embryonic fibroblasts; MI, myocardial infarction; MMPs, matrix metalloproteinases; MSCs, mesenchymal stem cells; mTORC1, Mammalian target of rapamycin complex 1; NF-YA, Nuclear transcription factor-Y alpha; NGFI-B or Nur77, nerve growth factor-induced gene B; NLS, nuclear localization signal; Nox4, Nicotinamide adenine dinucleotide phosphate oxidase 4; NSCLC, non-small-cell lung cancer; OSM, Oncostatin M; PEP, phosphoenolpyruvate; PD, peritoneal dialysis; PDGF, platelet-derived growth factor; PKC, protein kinase C; PKM2, pyruvate kinase M2; PHDs, prolyl hydroxylases; PI3K, phosphatidylinositol 
3-kinase; PIAS3, protein inhibitor of activated STAT; PGK, phosphoglycerate kinase 1; PKR, RNA-dependent protein kinase R; Pol II, RNA polymerase II; PRC2, polycomb repressive complex 2; Pyk2, proline-rich tyrosine kinase 2; Ref-1/APE, redox effector factor-1/ apurinic/apyrimidinic endonuclease; RECK, reversioninducing cysteine-rich protein with kazal motifs; RTKs, receptor tyrosine kinases; ROS, reactive oxygen species; SH2, Src homology 2; SHP-1, Src homology region2 domain-containing phosphatase-1; Sp1, specificity protein 1; SOCS3, suppressor of cytokine signal 3; STAT3, Signal transducer and activator of transcription factor 3; Th1, $\mathrm{T}$ helper 1; TNBC, triple-negative breast cancer; uPAR, urokinase receptor; TNF- $\alpha$, tumor necrosis factor- $\alpha$; UTR, untranslated region; VEGF, vascular endothelial growth factor; VSMCs, vascular smooth muscle cells.

\section{ACKNOWLEDGMENTS}

This study was supported by the grants from The National Natural Science Foundation of China (81370269, 81570255), Natural Science Foundation of Shandong Province (ZR2014HQ058) and Shandong Taishan Scholarship (Ju Liu).

\section{CONFLICTS OF INTEREST}

The authors declare no conflicts of interest.

\section{REFERENCES}

1. Birbrair A, Zhang T, Wang ZM, Messi ML, Olson JD, Mintz A, Delbono O. Type-2 pericytes participate in normal and tumoral angiogenesis. Am J Physiol Cell Physiol. 2014; 307:C25-38. https://doi.org/10.1152/ajpcell.00084.2014.

2. Birbrair A, Zhang T, Wang ZM, Messi ML, Mintz A, Delbono O. Pericytes at the intersection between tissue regeneration and pathology. Clin Sci (Lond). 2015; 128:8193. https://doi.org/10.1042/cs20140278.

3. Folkman J. Angiogenesis: an organizing principle for drug discovery? Nat Rev Drug Discov. 2007; 6:273-86. https:// doi.org/10.1038/nrd2115.

4. Carmeliet P. Angiogenesis in health and disease. Nat Med. 2003; 9:653-60. https://doi.org/10.1038/nm0603-653.

5. Weis SM, Cheresh DA. Tumor angiogenesis: molecular pathways and therapeutic targets. Nat Med. 2011; 17:135970. https://doi.org/10.1038/nm.2537.

6. Folkman J. Tumor angiogenesis: therapeutic implications. N Engl J Med. 1971; 285:1182-6. https://doi.org/10.1056/ nejm197111182852108.

7. Abe R. Angiogenesis in tumor growth and metastasis. Curr Pharm Des. 2008; 14:3779.

8. Hellmann K. Angiogenesis: tumour size is no guide to malignancy. Lancet Oncol. 2001; 2:259-60. https://doi. org/10.1016/s1470-2045(00)00319-3.
9. Zahn LM. Effects of the tumor microenvironment. Science. 2017; 355:1386-8. https://doi.org/10.1126/ science.355.6332.1386-1.

10. Herbert SP, Stainier DY. Molecular control of endothelial cell behaviour during blood vessel morphogenesis. Nat Rev Mol Cell Biol. 2011; 12:551-64. https://doi.org/10.1038/ nrm3176.

11. Jain RK. Antiangiogenesis strategies revisited: from starving tumors to alleviating hypoxia. Cancer Cell. 2014; 26:605-22. https://doi.org/10.1016/j.ccell.2014.10.006.

12. Dal Monte M, Martini D, Ristori C, Azara D, Armani C, Balbarini A, Bagnoli P. Hypoxia effects on proangiogenic factors in human umbilical vein endothelial cells: functional role of the peptide somatostatin. Naunyn Schmiedebergs Arch Pharmacol. 2011; 383:593-612. https://doi. org/10.1007/s00210-011-0625-y.

13. Carmeliet $P$, Jain RK. Molecular mechanisms and clinical applications of angiogenesis. Nature. 2011; 473:298-307. https://doi.org/10.1038/nature10144.

14. Neufeld G, Kessler O. Pro-angiogenic cytokines and their role in tumor angiogenesis. Cancer Metastasis Rev. 2006; 25:373-85. https://doi.org/10.1007/s10555-006-9011-5.

15. Dutzmann J, Daniel JM, Bauersachs J, Hilfiker-Kleiner D, Sedding DG. Emerging translational approaches to target STAT3 signalling and its impact on vascular disease. Cardiovasc Res. 2015; 106:365-74. https://doi.org/10.1093/ cvr/cvv103.

16. Raza SL, Cornelius LA. Matrix metalloproteinases: proand anti-angiogenic activities. J Investig Dermatol Symp Proc. 2000; 5:47-54. https://doi.org/10.1046/j.10870024.2000.00004.x.

17. Bazzoni G, Dejana E. Endothelial cell-to-cell junctions: molecular organization and role in vascular homeostasis. Physiol Rev. 2004; 84:869-901. https://doi.org/10.1152/ physrev.00035.2003.

18. Hashizume H, Baluk $\mathrm{P}$, Morikawa S, McLean JW, Thurston G, Roberge S, Jain RK, McDonald DM. Openings between defective endothelial cells explain tumor vessel leakiness. Am J Pathol. 2000; 156:1363-80. https://doi. org/10.1016/s0002-9440(10)65006-7.

19. Neve A, Cantatore FP, Maruotti N, Corrado A, Ribatti D. Extracellular matrix modulates angiogenesis in physiological and pathological conditions. Biomed Res Int. 2014; 2014:756078. https://doi.org/10.1155/2014/756078.

20. Darnell JE Jr. STATs and gene regulation. Science. 1997; 277:1630-5.

21. Adamson AS, Collins K, Laurence A, O'Shea JJ. The Current STATus of lymphocyte signaling: new roles for old players. Curr Opin Immunol. 2009; 21:161-6. https://doi. org/10.1016/j.coi.2009.03.013.

22. Bromberg J, Darnell JE Jr. The role of STATs in transcriptional control and their impact on cellular function. Oncogene. 2000; 19:2468-73. https://doi.org/10.1038/ sj.onc. 1203476 . 
23. Lim CP, Cao X. Structure, function, and regulation of STAT proteins. Mol Biosyst. 2006; 2:536-50. https://doi. org/10.1039/b606246f.

24. Zhu X, Zhou W. The Emerging Regulation of VEGFR-2 in Triple-Negative Breast Cancer. Front Endocrinol (Lausanne). 2015; 6:159. https://doi.org/10.3389/fendo.2015.00159.

25. Banerjee $\mathrm{K}$, Resat $\mathrm{H}$. Constitutive activation of STAT3 in breast cancer cells: A review. Int J Cancer. 2016; 138:2570 8. https://doi.org/10.1002/ijc.29923.

26. Levy DE, Darnell JE Jr. Stats: transcriptional control and biological impact. Nat Rev Mol Cell Biol. 2002; 3:651-62. https://doi.org/10.1038/nrm909.

27. Aziz MH, Hafeez BB, Sand JM, Pierce DB, Aziz SW, Dreckschmidt NE, Verma AK. Protein kinase Cvarepsilon mediates Stat3Ser727 phosphorylation, Stat3-regulated gene expression, and cell invasion in various human cancer cell lines through integration with MAPK cascade (RAF-1, MEK1/2, and ERK1/2). Oncogene. 2010; 29:3100-9. https://doi.org/10.1038/onc.2010.63.

28. Schindler C, Levy DE, Decker T. JAK-STAT signaling: from interferons to cytokines. J Biol Chem. 2007; 282:20059-63. https://doi.org/10.1074/jbc.R700016200.

29. Yuan ZL, Guan YJ, Chatterjee D, Chin YE. Stat3 dimerization regulated by reversible acetylation of a single lysine residue. Science. 2005; 307:269-73. https://doi. org/10.1126/science.1105166.

30. Yoshida Y, Kumar A, Koyama Y, Peng H, Arman A, Boch JA, Auron PE. Interleukin 1 activates STAT3/nuclear factor-kappaB cross-talk via a unique TRAF6- and p65dependent mechanism. J Biol Chem. 2004; 279:1768-76. https://doi.org/10.1074/jbc.M311498200.

31. Luo X, Ribeiro M, Bray ER, Lee DH, Yungher BJ, Mehta ST, Thakor KA, Diaz F, Lee JK, Moraes CT, Bixby JL, Lemmon VP, Park KK. Enhanced Transcriptional Activity and Mitochondrial Localization of STAT3 Co-induce Axon Regrowth in the Adult Central Nervous System. Cell Rep. 2016; 15:398-410. https://doi.org/10.1016/j.celrep.2016.03.029.

32. Meier JA, Hyun M. Stress-induced dynamic regulation of mitochondrial STAT3 and its association with cyclophilin D reduce mitochondrial ROS production. Sci Signal. 2017; 10. https://doi.org/10.1126/scisignal.aag2588.

33. Christofk HR, Vander Heiden MG, Wu N, Asara JM, Cantley LC. Pyruvate kinase M2 is a phosphotyrosinebinding protein. Nature. 2008; 452:181-6. https://doi. org/10.1038/nature06667.

34. Gao X, Wang H, Yang JJ, Liu X, Liu ZR. Pyruvate kinase M2 regulates gene transcription by acting as a protein kinase. Mol Cell. 2012; 45:598-609. https://doi. org/10.1016/j.molcel.2012.01.001.

35. Luo W, Hu H, Chang R, Zhong J, Knabel M, O’Meally R, Cole RN, Pandey A, Semenza GL. Pyruvate kinase M2 is a PHD3-stimulated coactivator for hypoxia-inducible factor 1. Cell. 2011; 145:732-44. https://doi.org/10.1016/j. cell.2011.03.054.
36. Yang W, Xia Y, Hawke D, Li X, Liang J, Xing D, Aldape K, Hunter T, Alfred Yung WK, Lu Z. PKM2 phosphorylates histone $\mathrm{H} 3$ and promotes gene transcription and tumorigenesis. Cell. 2012; 150:685-96. https://doi. org/10.1016/j.cell.2012.07.018.

37. Li Q, Zhang D, Chen X, He L, Li T, Xu X, Li M. Nuclear PKM2 contributes to gefitinib resistance via upregulation of STAT3 activation in colorectal cancer. Sci Rep. 2015; 5:16082. https://doi.org/10.1038/srep16082.

38. Liang J, Cao R, Zhang Y, Xia Y, Zheng Y, Li X, Wang L, Yang W, Lu Z. PKM2 dephosphorylation by Cdc25A promotes the Warburg effect and tumorigenesis. Nat Commun. 2016; 7:12431. https://doi.org/10.1038/ncomms12431.

39. Yang P, Li Z, Fu R, Wu H, Li Z. Pyruvate kinase M2 facilitates colon cancer cell migration via the modulation of STAT3 signalling. Cell Signal. 2014; 26:1853-62. https:// doi.org/10.1016/j.cellsig.2014.03.020.

40. Yang P, Li Z, Li H, Lu Y, Wu H, Li Z. Pyruvate kinase M2 accelerates pro-inflammatory cytokine secretion and cell proliferation induced by lipopolysaccharide in colorectal cancer. Cell Signal. 2015; 27:1525-32. https:// doi.org/10.1016/j.cellsig.2015.02.032.

41. Dong T, Yan Y, Chai H, Chen S, Xiong X, Sun D, Yu Y, Deng L, Cheng F. Pyruvate kinase M2 affects liver cancer cell behavior through up-regulation of HIF-1alpha and Bcl$x L$ in culture. Biomed Pharmacother. 2015; 69:277-84. https://doi.org/10.1016/j.biopha.2014.12.010.

42. Demaria M, Poli V. PKM2, STAT3 and HIF-1alpha: The Warburg's vicious circle. JAKSTAT. 2012; 1:194-6. https:// doi.org/10.4161/jkst.20662.

43. O'Shea JJ, Kanno Y, Chen X, Levy DE. Cell signaling. Stat acetylation--a key facet of cytokine signaling? Science. 2005; 307:217-8. https://doi.org/10.1126/science.1108164.

44. Ray S, Boldogh I, Brasier AR. STAT3 NH2-terminal acetylation is activated by the hepatic acute-phase response and required for IL-6 induction of angiotensinogen. Gastroenterology. 2005; 129:1616-32. https://doi. org/10.1053/j.gastro.2005.07.055.

45. Nie Y, Erion DM, Yuan Z, Dietrich M, Shulman GI, Horvath TL, Gao Q. STAT3 inhibition of gluconeogenesis is downregulated by SirT1. Nat Cell Biol. 2009; 11:492-500. https://doi.org/10.1038/ncb1857.

46. Schaefer TS, Sanders LK, Nathans D. Cooperative transcriptional activity of Jun and Stat3 beta, a short form of Stat3. Proc Natl Acad Sci USA. 1995; 92:9097-101.

47. Darnowski JW, Goulette FA, Guan YJ, Chatterjee D, Yang ZF, Cousens LP, Chin YE. Stat3 cleavage by caspases: impact on full-length Stat3 expression, fragment formation, and transcriptional activity. J Biol Chem. 2006; 281:17707-17. https://doi.org/10.1074/jbc.M600088200.

48. Takeda K, Noguchi K, Shi W, Tanaka T, Matsumoto M, Yoshida N, Kishimoto T, Akira S. Targeted disruption of the mouse Stat 3 gene leads to early embryonic lethality. Proc Natl Acad Sci USA. 1997; 94:3801-4. 
49. Maritano D, Sugrue ML, Tininini S, Dewilde S, Strobl B, Fu X, Murray-Tait V, Chiarle R, Poli V. The STAT3 isoforms alpha and beta have unique and specific functions. Nat Immunol. 2004; 5:401-9. https://doi.org/10.1038/ ni1052.

50. Yoo JY, Huso DL, Nathans D, Desiderio S. Specific ablation of Stat3beta distorts the pattern of Stat3-responsive gene expression and impairs recovery from endotoxic shock. Cell. 2002; 108:331-44.

51. Kano A, Wolfgang MJ, Gao Q, Jacoby J, Chai GX, Hansen W, Iwamoto Y, Pober JS, Flavell RA, Fu XY. Endothelial cells require STAT3 for protection against endotoxin-induced inflammation. J Exp Med. 2003; 198:1517-25. https://doi.org/10.1084/jem.20030077.

52. Wang M, Zhang W, Crisostomo P, Markel T, Meldrum KK, Fu XY, Meldrum DR. Endothelial STAT3 plays a critical role in generalized myocardial proinflammatory and proapoptotic signaling. Am J Physiol Heart Circ Physiol. 2007; 293:H2101-8. https://doi.org/10.1152/ ajpheart.00125.2007.

53. Wang M, Zhang W, Crisostomo P, Markel T, Meldrum KK, Fu XY, Meldrum DR. Sex differences in endothelial STAT3 mediate sex differences in myocardial inflammation. Am J Physiol Endocrinol Metab. 2007; 293:E872-7. https://doi. org/10.1152/ajpendo.00251.2007.

54. Hilfiker-Kleiner D, Hilfiker A, Fuchs M, Kaminski K, Schaefer A, Schieffer B, Hillmer A, Schmiedl A, Ding Z, Podewski E, Podewski E, Poli V, Schneider MD, et al. Signal transducer and activator of transcription 3 is required for myocardial capillary growth, control of interstitial matrix deposition, and heart protection from ischemic injury. Circ Res. 2004; 95:187-95. https://doi. org/10.1161/01.res.0000134921.50377.61.

55. Edelberg JM, Reed MJ. Aging and angiogenesis. Front Biosci. 2003; 8:s1199-209.

56. Volpert OV, Zaichuk T, Zhou W, Reiher F, Ferguson TA, Stuart PM, Amin M, Bouck NP. Inducer-stimulated Fas targets activated endothelium for destruction by antiangiogenic thrombospondin-1 and pigment epitheliumderived factor. Nat Med. 2002; 8:349-57. https://doi. org/10.1038/nm0402-349.

57. Inoki I, Shiomi T, Hashimoto G, Enomoto H, Nakamura H, Makino K, Ikeda E, Takata S, Kobayashi K, Okada Y. Connective tissue growth factor binds vascular endothelial growth factor (VEGF) and inhibits VEGF-induced angiogenesis. FASEB J. 2002; 16:219-21. https://doi.org/10.1096/fj.01-0332fje.

58. Rodriguez-Manzaneque JC, Lane TF, Ortega MA, Hynes RO, Lawler J, Iruela-Arispe ML. Thrombospondin-1 suppresses spontaneous tumor growth and inhibits activation of matrix metalloproteinase-9 and mobilization of vascular endothelial growth factor. Proc Natl Acad Sci USA. 2001; 98:12485-90. https://doi.org/10.1073/pnas.171460498.

59. Wang M, Zhang W, Crisostomo P, Markel T, Meldrum KK, Fu XY, Meldrum DR. STAT3 mediates bone marrow mesenchymal stem cell VEGF production. J Mol Cell Cardiol. 2007; 42:1009-15. https://doi.org/10.1016/j. yjmcc.2007.04.010.

60. Kostromina E, Wang X, Han W. Altered islet morphology but normal islet secretory function in vitro in a mouse model with microvascular alterations in the pancreas. PLoS One. 2013; 8:e71277. https://doi.org/10.1371/journal. pone. 0071277 .

61. Chen Z, Han ZC. STAT3: a critical transcription activator in angiogenesis. Med Res Rev. 2008; 28:185-200. https://doi. org $/ 10.1002 /$ med.20101.

62. Gray MJ, Zhang J, Ellis LM, Semenza GL, Evans DB, Watowich SS, Gallick GE. HIF-1alpha, STAT3, CBP/p300 and Ref-1/APE are components of a transcriptional complex that regulates Src-dependent hypoxia-induced expression of VEGF in pancreatic and prostate carcinomas. Oncogene. 2005; 24:3110-20. https://doi.org/10.1038/sj.onc.1208513.

63. Pawlus MR, Wang L, Hu CJ. STAT3 and HIF1alpha cooperatively activate HIF1 target genes in MDA-MB-231 and RCC4 cells. Oncogene. 2014; 33:1670-9. https://doi. org/10.1038/onc.2013.115.

64. Niu G, Wright KL, Huang M, Song L, Haura E, Turkson J, Zhang S, Wang T, Sinibaldi D, Coppola D, Heller R, Ellis LM, Karras J, et al. Constitutive Stat 3 activity up-regulates VEGF expression and tumor angiogenesis. Oncogene. 2002; 21:2000-8. https://doi.org/10.1038/sj.onc.1205260.

65. Zhao M, Gao FH, Wang JY, Liu F, Yuan HH, Zhang WY, Jiang B. JAK2/STAT3 signaling pathway activation mediates tumor angiogenesis by upregulation of VEGF and bFGF in non-small-cell lung cancer. Lung Cancer. 2011; 73:366-74. https://doi.org/10.1016/j.lungcan.2011.01.002.

66. Wei LH, Kuo ML, Chen CA, Chou CH, Lai KB, Lee CN, Hsieh CY. Interleukin-6 promotes cervical tumor growth by VEGF-dependent angiogenesis via a STAT3 pathway. Oncogene. 2003; 22:1517-27. https://doi.org/10.1038/ sj.onc. 1206226 .

67. Hansen MF, Greibe E, Skovbjerg S, Rohde S, Kristensen AC, Jensen TR, Stentoft C, Kjaer KH, Kronborg CS, Martensen PM. Folic acid mediates activation of the pro-oncogene STAT3 via the Folate Receptor alpha. Cell Signal. 2015; 27:1356-68. https://doi.org/10.1016/j. cellsig.2015.03.020.

68. Lu YM, Chen W, Zhu JS, Chen WX, Chen NW. Eriocalyxin B blocks human SW1116 colon cancer cell proliferation, migration, invasion, cell cycle progression and angiogenesis via the JAK2/STAT3 signaling pathway. Mol Med Rep. 2016; 13:2235-40. https://doi.org/10.3892/mmr.2016.4800.

69. Xie TX, Wei D, Liu M, Gao AC, Ali-Osman F, Sawaya R, Huang S. Stat3 activation regulates the expression of matrix metalloproteinase-2 and tumor invasion and metastasis. Oncogene. 2004; 23:3550-60. https://doi.org/10.1038/ sj.onc. 1207383 .

70. Walsh LA, Roy DM, Reyngold M, Giri D, Snyder A, Turcan S, Badwe CR, Lyman J, Bromberg J, King TA, Chan TA. 
RECK controls breast cancer metastasis by modulating a convergent, STAT3-dependent neoangiogenic switch. Oncogene. 2015; 34:2189-203. https://doi.org/10.1038/ onc. 2014.175

71. Liu Y, Luo F, Wang B, Li H, Xu Y, Liu X, Shi L, Lu X, $\mathrm{Xu} \mathrm{W,} \mathrm{Lu} \mathrm{L,} \mathrm{Qin} \mathrm{Y,} \mathrm{Xiang} \mathrm{Q,} \mathrm{Liu} \mathrm{Q.} \mathrm{STAT3-regulated}$ exosomal miR-21 promotes angiogenesis and is involved in neoplastic processes of transformed human bronchial epithelial cells. Cancer Lett. 2016; 370:125-35. https://doi. org/10.1016/j.canlet.2015.10.011.

72. Zhuang G, Wu X, Jiang Z, Kasman I, Yao J, Guan Y, Oeh J, Modrusan Z, Bais C, Sampath D, Ferrara N. Tumoursecreted miR-9 promotes endothelial cell migration and angiogenesis by activating the JAK-STAT pathway. EMBO J. 2012; 31:3513-23. https://doi.org/10.1038/emboj.2012.183.

73. Kujawski M, Kortylewski M, Lee H, Herrmann A, Kay $\mathrm{H}, \mathrm{Yu} \mathrm{H}$. Stat3 mediates myeloid cell-dependent tumor angiogenesis in mice. J Clin Invest. 2008; 118:3367-77. https://doi.org/10.1172/jci35213.

74. Koch S, Claesson-Welsh L. Signal transduction by vascular endothelial growth factor receptors. Cold Spring Harb Perspect Med. 2012; 2:a006502. https://doi.org/10.1101/ cshperspect.a006502.

75. Okazaki H, Tokumaru S, Hanakawa Y, Shiraishi K, Shirakata Y, Dai X, Yang L, Tohyama M, Hashimoto K, Sayama K. Nuclear translocation of phosphorylated STAT3 regulates VEGF-A-induced lymphatic endothelial cell migration and tube formation. Biochem Biophys Res Commun. 2011; 412:441-5. https://doi.org/10.1016/j.bbrc.2011.07.111.

76. Yahata Y, Shirakata Y, Tokumaru S, Yamasaki K, Sayama K, Hanakawa Y, Detmar M, Hashimoto K. Nuclear translocation of phosphorylated STAT3 is essential for vascular endothelial growth factor-induced human dermal microvascular endothelial cell migration and tube formation. J Biol Chem. 2003; 278:40026-31. https://doi. org/10.1074/jbc.M301866200.

77. Fee D, Grzybicki D, Dobbs M, Ihyer S, Clotfelter J, Macvilay S, Hart MN, Sandor M, Fabry Z. Interleukin 6 promotes vasculogenesis of murine brain microvessel endothelial cells. Cytokine. 2000; 12:655-65. https://doi. org/10.1006/cyto.1999.0599.

78. Magrini E, Cavallaro U, Bianchi F. Microarray profiling of L1-overexpressing endothelial cells reveals STAT3 activation via IL-6/IL-6Ralpha axis. Genom Data. 2015; 4:137-9. https://doi.org/10.1016/j.gdata.2015.03.017.

79. Santra M, Santra S, Zhang J, Chopp M. Ectopic decorin expression up-regulates VEGF expression in mouse cerebral endothelial cells via activation of the transcription factors Sp1, HIF1alpha, and Stat3. J Neurochem. 2008; 105:324-37. https://doi.org/10.1111/j.1471-4159.2007.05134.x.

80. Zhu WQ, Wang J, Guo XF, Liu Z, Dong WG. Thymoquinone inhibits proliferation in gastric cancer via the STAT3 pathway in vivo and in vitro. World J Gastroenterol. 2016; 22:4149-59. https://doi.org/10.3748/ wjg.v22.i16.4149.
81. Zhu H, Xiao F, Wang G, Wei X, Jiang L, Chen Y, Zhu L, Wang H, Diao Y, Wang H, Ip NY, Cheung TH, Wu Z. STAT3 Regulates Self-Renewal of Adult Muscle Satellite Cells during Injury-Induced Muscle Regeneration. Cell Rep. 2016; 16:2102-15. https://doi.org/10.1016/j. celrep.2016.07.041.

82. Xue H, Yuan G, Guo X, Liu Q, Zhang J, Gao X, Guo $\mathrm{X}, \mathrm{Xu} \mathrm{S}, \mathrm{Li} \mathrm{T}$, Shao Q, Yan S, Li G. A novel tumorpromoting mechanism of IL6 and the therapeutic efficacy of tocilizumab: Hypoxia-induced IL6 is a potent autophagy initiator in glioblastoma via the p-STAT3-MIR155-3pCREBRF pathway. Autophagy. 2016; 12:1129-52. https:// doi.org/10.1080/15548627.2016.1178446.

83. Xu Z, Sun Y, Guo Y, Qin G, Mu S, Fan R, Wang B, Gao $\mathrm{W}$, Wu H, Wang G, Zhang Z. NF-YA promotes invasion and angiogenesis by upregulating EZH2-STAT3 signaling in human melanoma cells. Oncol Rep. 2016; 35:3630-8. https://doi.org/10.3892/or.2016.4761.

84. Zhao D, Pan C, Sun J, Gilbert C, Drews-Elger K, Azzam DJ, Picon-Ruiz M, Kim M, Ullmer W, El-Ashry D, Creighton CJ, Slingerland JM. VEGF drives cancer-initiating stem cells through VEGFR-2/Stat3 signaling to upregulate Myc and Sox2. Oncogene. 2015; 34:3107-19. https://doi. org/10.1038/onc.2014.257.

85. Wang Y, Li JX, Wang YQ, Miao ZH. Tanshinone I inhibits tumor angiogenesis by reducing Stat3 phosphorylation at Tyr705 and hypoxia-induced HIF- $1 \alpha$ accumulation in both endothelial and tumor cells. Oncotarget. 2015; 6:16031-42. https://doi.org/10.18632/oncotarget.3648.

86. Sun X, Zhang J, Hou Z, Han Q, Zhang C, Tian Z. miR-146a is directly regulated by STAT3 in human hepatocellular carcinoma cells and involved in anti-tumor immune suppression. Cell Cycle. 2015; 14:243-52. https://doi.org/ 10.4161/15384101.2014.977112.

87. Xu X, Kriegel AJ, Jiao X, Liu H, Bai X, Olson J, Liang M, Ding X. miR-21 in ischemia/reperfusion injury: a doubleedged sword? Physiol Genomics. 2014; 46:789-97. https:// doi.org/10.1152/physiolgenomics.00020.2014.

88. Siveen KS, Sikka S, Surana R, Dai X, Zhang J, Kumar AP, Tan BK, Sethi G, Bishayee A. Targeting the STAT3 signaling pathway in cancer: role of synthetic and natural inhibitors. Biochim Biophys Acta. 2014; 1845:136-54. https://doi.org/10.1016/j.bbcan.2013.12.005.

89. Cobler L, Pera M, Garrido M, Iglesias M, de Bolos C. CDX2 can be regulated through the signalling pathways activated by IL-6 in gastric cells. Biochim Biophys Acta. 2014; 1839:785-92. https://doi.org/10.1016/j.bbagrm.2014.06.009.

90. Cao C, Zhao G, Yu W, Xie X, Wang W, Yang R, Lv X, Liu D. Activation of STAT3 stimulates AHSP expression in K562 cells. Sci China Life Sci. 2014; 57:488-94. https:// doi.org/10.1007/s11427-014-4652-z.

91. Wieczorek M, Ginter T, Brand P, Heinzel T, Kramer OH. Acetylation modulates the STAT signaling code. Cytokine Growth Factor Rev. 2012; 23:293-305. https://doi. org/10.1016/j.cytogfr.2012.06.005. 
92. Paulin R, Meloche J, Bonnet S. STAT3 signaling in pulmonary arterial hypertension. JAKSTAT. 2012; 1:223-33. https://doi.org/10.4161/jkst.22366.

93. Mencalha AL, Binato R, Ferreira GM, Du Rocher B, Abdelhay E. Forkhead box M1 (FoxM1) gene is a new STAT3 transcriptional factor target and is essential for proliferation, survival and DNA repair of K562 cell line. PLoS One. 2012; 7:e48160. https://doi.org/10.1371/journal. pone. 0048160 .

94. Lee H, Zhang P, Herrmann A, Yang C, Xin H, Wang Z, Hoon DS, Forman SJ, Jove R, Riggs AD, Yu H. Acetylated STAT3 is crucial for methylation of tumor-suppressor gene promoters and inhibition by resveratrol results in demethylation. Proc Natl Acad Sci USA. 2012; 109:7765-9. https://doi.org/10.1073/pnas.1205132109.

95. Mikami Y, Asano M, Honda MJ, Takagi M. Bone morphogenetic protein 2 and dexamethasone synergistically increase alkaline phosphatase levels through JAK/STAT signaling in C3H10T1/2 cells. J Cell Physiol. 2010; 223:123-33. https://doi.org/10.1002/jcp.22017.

96. Zhang Q, Wang HY, Marzec M, Raghunath PN, Nagasawa T, Wasik MA. STAT3- and DNA methyltransferase 1-mediated epigenetic silencing of SHP-1 tyrosine phosphatase tumor suppressor gene in malignant $\mathrm{T}$ lymphocytes. Proc Natl Acad Sci USA. 2005; 102:6948-53. https://doi.org/10.1073/pnas.0501959102.

97. Wung BS, Hsu MC, Wu CC, Hsieh CW. Resveratrol suppresses IL-6-induced ICAM-1 gene expression in endothelial cells: effects on the inhibition of STAT3 phosphorylation. Life Sci. 2005; 78:389-97. https://doi. org/10.1016/j.1fs.2005.04.052.

98. Dalwadi H, Krysan K, Heuze-Vourc'h N, Dohadwala M, Elashoff D, Sharma S, Cacalano N, Lichtenstein A, Dubinett S. Cyclooxygenase-2-dependent activation of signal transducer and activator of transcription 3 by interleukin-6 in non-small cell lung cancer. Clin Cancer Res. 2005; 11:7674-82. https://doi.org/10.1158/1078-0432. ccr-05-1205.

99. Koh J, Jang JY, Keam B, Kim S, Kim MY, Go H, Kim TM, Kim DW, Kim CW, Jeon YK, Chung DH. EML4ALK enhances programmed cell death-ligand 1 expression in pulmonary adenocarcinoma via hypoxia-inducible factor (HIF)-1alpha and STAT3. Oncoimmunology. 2016; 5:e1108514. https://doi.org/10.1080/2162402x.2015.1108514.

100. Welti J, Loges S, Dimmeler S, Carmeliet P. Recent molecular discoveries in angiogenesis and antiangiogenic therapies in cancer. J Clin Invest. 2013; 123:3190-200. https://doi.org/10.1172/jci70212.

101. Hutchins AP, Poulain S, Miranda-Saavedra D. Genomewide analysis of STAT3 binding in vivo predicts effectors of the anti-inflammatory response in macrophages. Blood. 2012; 119:e110-9. https://doi.org/10.1182/ blood-2011-09-381483.

102. Ho HH, Ivashkiv LB. Role of STAT3 in type I interferon responses. Negative regulation of STAT1-dependent inflammatory gene activation. J Biol Chem. 2006; 281:14111-8. https://doi.org/10.1074/jbc.M511797200.

103. Kortylewski M, Kujawski M, Wang T, Wei S, Zhang S, Pilon-Thomas S, Niu G, Kay H, Mule J, Kerr WG, Jove $\mathrm{R}$, Pardoll D, Yu H. Inhibiting Stat3 signaling in the hematopoietic system elicits multicomponent antitumor immunity. Nat Med. 2005; 11:1314-21. https://doi. org/10.1038/nm1325.

104. Shen Y, Devgan G, Darnell JE Jr, Bromberg JF. Constitutively activated Stat 3 protects fibroblasts from serum withdrawal and UV-induced apoptosis and antagonizes the proapoptotic effects of activated Stat1. Proc Natl Acad Sci USA. 2001; 98:1543-8. https://doi. org/10.1073/pnas.041588198.

105. Kang K, Robinson GW, Hennighausen L. Comprehensive meta-analysis of Signal Transducers and Activators of Transcription (STAT) genomic binding patterns discerns cell-specific cis-regulatory modules. BMC Genomics. 2013; 14:4. https://doi.org/10.1186/1471-2164-14-4.

106. Wang H, Holloway MP, Ma L, Cooper ZA, Riolo M, Samkari A, Elenitoba-Johnson KS, Chin YE, Altura RA. Acetylation directs survivin nuclear localization to repress STAT3 oncogenic activity. J Biol Chem. 2010; 285:3612937. https://doi.org/10.1074/jbc.M110.152777.

107. Chen Y, Wu R, Chen HZ, Xiao Q, Wang WJ, He JP, Li XX, Yu XW, Li L, Wang P, Wan XC, Tian XH, Li SJ, et al. Enhancement of hypothalamic STAT3 acetylation by nuclear receptor Nur77 dictates leptin sensitivity. Diabetes. 2015; 64:2069-81. https://doi.org/10.2337/db14-1206.

108. Zeng H, Qin L, Zhao D, Tan X, Manseau EJ, Van Hoang M, Senger DR, Brown LF, Nagy JA, Dvorak HF. Orphan nuclear receptor TR3/Nur77 regulates VEGF-A-induced angiogenesis through its transcriptional activity. J Exp Med. 2006; 203:719-29. https://doi.org/10.1084/jem.20051523.

109. Zhao D, Qin L, Bourbon PM, James L, Dvorak HF, Zeng H. Orphan nuclear transcription factor TR3/Nur77 regulates microvessel permeability by targeting endothelial nitric oxide synthase and destabilizing endothelial junctions. Proc Natl Acad Sci USA. 2011; 108:12066-71. https://doi. org/10.1073/pnas.1018438108.

110. Niu G, Ye T, Qin L, Bourbon PM, Chang C, Zhao S, Li Y, Zhou L, Cui P, Rabinovitz I, Mercurio AM, Zhao D, Zeng H. Orphan nuclear receptor TR3/Nur77 improves wound healing by upregulating the expression of integrin beta4. FASEB J. 2015; 29:131-40. https://doi.org/10.1096/ fj.14-257550.

111. Li J, Cui G, Sun L, Wang SJ, Li YL, Meng YG, Guan Z, Fan WS, Li LA, Yang YZ, You YQ, Fu XY, Yan ZF, et al. STAT3 acetylation-induced promoter methylation is associated with downregulation of the ARHI tumor-suppressor gene in ovarian cancer. Oncol Rep. 2013; 30:165-70. https://doi. org/10.3892/or.2013.2414.

112. Kang HJ, Yi YW, Hou SJ, Kim HJ, Kong Y, Bae I, Brown ML. Disruption of STAT3-DNMT1 interaction by SH-I14 induces re-expression of tumor suppressor genes and 
inhibits growth of triple-negative breast tumor. Oncotarget. 2015 May 9. https://doi.org/10.18632/oncotarget.4054. [Epub ahead of print]

113. Yeh CM, Chang LY, Lin SH, Chou JL, Hsieh HY, Zeng LH, Chuang SY, Wang HW, Dittner C, Lin CY, Lin JM, Huang YT, Ng EK, et al. Epigenetic silencing of the NR4A3 tumor suppressor, by aberrant JAK/STAT signaling, predicts prognosis in gastric cancer. Sci Rep. 2016; 6:31690. https:// doi.org/10.1038/srep31690.

114. Niu G, Wright KL, Ma Y, Wright GM, Huang M, Irby R, Briggs J, Karras J, Cress WD, Pardoll D, Jove R, Chen J, Yu $\mathrm{H}$. Role of Stat3 in regulating p53 expression and function. Mol Cell Biol. 2005; 25:7432-40. https://doi.org/10.1128/ mcb.25.17.7432-7440.2005.

115. Ravi R, Mookerjee B, Bhujwalla ZM, Sutter CH, Artemov D, Zeng Q, Dillehay LE, Madan A, Semenza GL, Bedi A. Regulation of tumor angiogenesis by p53-induced degradation of hypoxia-inducible factor 1alpha. Genes Dev. $2000 ; 14: 34-44$.

116. Fontemaggi G, Dell'Orso S, Trisciuoglio D, Shay T, Melucci E, Fazi F, Terrenato I, Mottolese M, Muti P, Domany E, Del Bufalo D, Strano S, Blandino G. The execution of the transcriptional axis mutant p53, E2F1 and ID4 promotes tumor neo-angiogenesis. Nat Struct Mol Biol. 2009; 16:1086-93. https://doi.org/10.1038/nsmb.1669.

117. Rathinavelu A, Narasimhan M, Muthumani P. A novel regulation of VEGF expression by HIF-1alpha and STAT3 in HDM2 transfected prostate cancer cells. J Cell Mol Med. 2012; 16:1750-7. https://doi.org/10.1111/j.15824934.2011.01472.x.

118. Xia M, Bi K, Huang R, Cho MH, Sakamuru S, Miller SC, Li H, Sun Y, Printen J, Austin CP, Inglese J. Identification of small molecule compounds that inhibit the HIF-1 signaling pathway. Mol Cancer. 2009; 8:117. https://doi. org/10.1186/1476-4598-8-117.

119. Jung JE, Lee HG, Cho IH, Chung DH, Yoon SH, Yang YM, Lee JW, Choi S, Park JW, Ye SK, Chung MH. STAT3 is a potential modulator of HIF-1-mediated VEGF expression in human renal carcinoma cells. FASEB J. 2005; 19:1296-8. https://doi.org/10.1096/fj.04-3099fje.

120. Prasad S, Gupta SC, Tyagi AK. Reactive oxygen species (ROS) and cancer: Role of antioxidative nutraceuticals. Cancer Lett. 2017; 387:95-105. https://doi.org/10.1016/j. canlet.2016.03.042.

121. Yu MO, Park KJ, Park DH, Chung YG, Chi SG, Kang SH. Reactive oxygen species production has a critical role in hypoxia-induced Stat 3 activation and angiogenesis in human glioblastoma. J Neurooncol. 2015; 125:55-63. https://doi.org/10.1007/s11060-015-1889-8.

122. Papadakis AI, Paraskeva E, Peidis P, Muaddi H, Li S, Raptis L, Pantopoulos K, Simos G, Koromilas AE. eIF2\{alpha\} Kinase PKR modulates the hypoxic response by Stat3dependent transcriptional suppression of HIF-1 \{alpha\}. Cancer Res. 2010; 70:7820-9. https://doi.org/10.1158/00085472.can-10-0215.
123. Dodd KM, Yang J, Shen MH, Sampson JR, Tee AR. mTORC1 drives HIF-1alpha and VEGF-A signalling via multiple mechanisms involving 4E-BP1, S6K1 and STAT3. Oncogene. 2015; 34:2239-50. https://doi.org/10.1038/ onc.2014.164.

124. Kumar R, Singh NK, Rao GN. Proline-rich tyrosine kinase 2 via enhancing signal transducer and activator of transcription 3-dependent cJun expression mediates retinal neovascularization. Sci Rep. 2016; 6:26480. https://doi. org/10.1038/srep26480.

125. Li L, Xu M, Li X, Lv C, Zhang X, Yu H, Zhang M, Fu Y, Meng H, Zhou J. Platelet-derived growth factor-B (PDGF-B) induced by hypoxia promotes the survival of pulmonary arterial endothelial cells through the PI3K/Akt/ Stat3 pathway. Cell Physiol Biochem. 2015; 35:441-51. https://doi.org/10.1159/000369709.

126. Lee SH, Lee JH, Han YS, Ryu JM, Yoon YM, Han HJ. Hypoxia accelerates vascular repair of endothelial colonyforming cells on ischemic injury via STAT3-BCL3 axis. Stem Cell Res Ther. 2015; 6:139. https://doi.org/10.1186/ s13287-015-0128-8.

127. Coussens LM, Werb Z. Inflammation and cancer. Nature. 2002; 420:860-7. https://doi.org/10.1038/nature01322.

128. Mantovani A, Allavena P, Sica A, Balkwill F. Cancerrelated inflammation. Nature. 2008; 454:436-44. https:// doi.org/10.1038/nature07205.

129. Zisman TL, Rubin DT. Colorectal cancer and dysplasia in inflammatory bowel disease. World J Gastroenterol. 2008; 14:2662-9.

130. Yu H, Pardoll D, Jove R. STATs in cancer inflammation and immunity: a leading role for STAT3. Nat Rev Cancer. 2009; 9:798-809. https://doi.org/10.1038/nrc2734.

131. Ernst M, Najdovska M, Grail D, Lundgren-May T, Buchert M, Tye H, Matthews VB, Armes J, Bhathal PS, Hughes NR, Marcusson EG, Karras JG, Na S, et al. STAT3 and STAT1 mediate IL-11-dependent and inflammationassociated gastric tumorigenesis in gp130 receptor mutant mice. J Clin Invest. 2008; 118:1727-38. https://doi. org/10.1172/jci34944.

132. Hoentjen F, Sartor RB, Ozaki M, Jobin C. STAT3 regulates NF-kappaB recruitment to the IL-12p40 promoter in dendritic cells. Blood. 2005; 105:689-96. https://doi. org/10.1182/blood-2004-04-1309.

133. Pfitzner E, Kliem S, Baus D, Litterst CM. The role of STATs in inflammation and inflammatory diseases. Curr Pharm Des. 2004; 10:2839-50.

134. Kobierski LA, Srivastava S, Borsook D. Systemic lipopolysaccharide and interleukin-1beta activate the interleukin 6: STAT intracellular signaling pathway in neurons of mouse trigeminal ganglion. Neurosci Lett. 2000; 281:61-4.

135. Ara T, Declerck YA. Interleukin-6 in bone metastasis and cancer progression. Eur J Cancer. 2010; 46:1223-31. https://doi.org/10.1016/j.ejca.2010.02.026. 
136. Qu Z, Sun F, Zhou J, Li L, Shapiro SD, Xiao G. Interleukin-6 Prevents the Initiation but Enhances the Progression of Lung Cancer. Cancer Res. 2015; 75:320915. https://doi.org/10.1158/0008-5472.can-14-3042.

137. Guo Y, Xu F, Lu T, Duan Z, Zhang Z. Interleukin-6 signaling pathway in targeted therapy for cancer. Cancer Treat Rev. 2012; 38:904-10. https://doi.org/10.1016/j. ctrv.2012.04.007.

138. Yadav A, Kumar B, Datta J, Teknos TN, Kumar P. IL-6 promotes head and neck tumor metastasis by inducing epithelial-mesenchymal transition via the JAK-STAT3SNAIL signaling pathway. Mol Cancer Res. 2011; 9:165867. https://doi.org/10.1158/1541-7786.mcr-11-0271.

139. Nilsson MB, Langley RR, Fidler IJ. Interleukin-6, secreted by human ovarian carcinoma cells, is a potent proangiogenic cytokine. Cancer Res. 2005; 65:10794-800. https://doi.org/10.1158/0008-5472.can-05-0623.

140. Shinriki S, Jono H, Ueda M, Ota K, Ota T, Sueyoshi T, Oike Y, Ibusuki M, Hiraki A, Nakayama H, Shinohara M, Ando Y. Interleukin-6 signalling regulates vascular endothelial growth factor-C synthesis and lymphangiogenesis in human oral squamous cell carcinoma. J Pathol. 2011; 225:142-50. https://doi.org/10.1002/path.2935.

141. Neiva KG, Zhang Z, Miyazawa M, Warner KA, Karl E, Nor JE. Cross talk initiated by endothelial cells enhances migration and inhibits anoikis of squamous cell carcinoma cells through STAT3/Akt/ERK signaling. Neoplasia. 2009; 11:583-93.

142. Neiva KG, Warner KA, Campos MS, Zhang Z, Moren J, Danciu TE, Nor JE. Endothelial cell-derived interleukin-6 regulates tumor growth. BMC Cancer. 2014; 14:99. https:// doi.org/10.1186/1471-2407-14-99.

143. Mejias-Luque R, Peiro S, Vincent A, Van Seuningen I, de Bolos C. IL-6 induces MUC4 expression through gp130/STAT3 pathway in gastric cancer cell lines. Biochim Biophys Acta. 2008; 1783:1728-36. https://doi. org/10.1016/j.bbamcr.2008.05.020.

144. Lopez-Ferrer A, de Bolos C, Barranco C, Garrido M, Isern J, Carlstedt I, Reis CA, Torrado J, Real FX. Role of fucosyltransferases in the association between apomucin and Lewis antigen expression in normal and malignant gastric epithelium. Gut. 2000; 47:349-56.

145. Jee SH, Chu CY, Chiu HC, Huang YL, Tsai WL, Liao YH, Kuo ML. Interleukin-6 induced basic fibroblast growth factor-dependent angiogenesis in basal cell carcinoma cell line via JAK/STAT3 and PI3-kinase/Akt pathways. J Invest Dermatol. 2004; 123:1169-75. https://doi.org/10.1111/ j.0022-202X.2004.23497.x.

146. Wei D, Le X, Zheng L, Wang L, Frey JA, Gao AC, Peng Z, Huang S, Xiong HQ, Abbruzzese JL, Xie K. Stat3 activation regulates the expression of vascular endothelial growth factor and human pancreatic cancer angiogenesis and metastasis. Oncogene. 2003; 22:319-29. https://doi. org/10.1038/sj.onc. 1206122 .
147. Huang YH, Yang HY, Hsu YF, Chiu PT, Ou G, Hsu MJ. Src contributes to IL6-induced vascular endothelial growth factor-C expression in lymphatic endothelial cells. Angiogenesis. 2014; 17:407-18. https://doi.org/10.1007/ s10456-013-9386-1.

148. Osuka K, Watanabe Y, Usuda N, Aoyama M, Kawaguchi R, Watabe T, Takayasu M. Activation of Signal Transducer and Activator of Transcription 3 in Endothelial Cells of Chronic Subdural Hematoma Outer Membranes. World Neurosurg. 2016; 91:376-82. https://doi.org/10.1016/j. wneu.2016.04.025.

149. Yang X, Lin A, Jiang N, Yan H, Ni Z, Qian J, Fang W. Interleukin- 6 trans-signalling induces vascular endothelial growth factor synthesis partly via Janus kinases-STAT3 pathway in human mesothelial cells. Nephrology (Carlton). 2017; 22:150-8. https://doi.org/10.1111/nep.12746.

150. Gu FM, Li QL, Gao Q, Jiang JH, Zhu K, Huang XY, Pan JF, Yan J, Hu JH, Wang Z, Dai Z, Fan J, Zhou J. IL-17 induces AKT-dependent IL-6/JAK2/STAT3 activation and tumor progression in hepatocellular carcinoma. Mol Cancer. 2011; 10:150. https://doi.org/10.1186/1476-4598-10-150.

151. Wang L, Yi T, Kortylewski M, Pardoll DM, Zeng D, Yu H. IL-17 can promote tumor growth through an IL-6-Stat3 signaling pathway. J Exp Med. 2009; 206:1457-64. https:// doi.org/10.1084/jem.20090207.

152. Wu X, Yang T, Liu X, Guo JN, Xie T, Ding Y, Lin M, Yang H. IL-17 promotes tumor angiogenesis through Stat3 pathway mediated upregulation of VEGF in gastric cancer. Tumour Biol. 2016; 37:5493-501. https://doi.org/10.1007/ s13277-015-4372-4.

153. Yuan S, Zhang S, Zhuang Y, Zhang H, Bai J, Hou Q. Interleukin-17 Stimulates STAT3-Mediated Endothelial Cell Activation for Neutrophil Recruitment. Cell Physiol Biochem. 2015; 36:2340-56. https://doi. org/10.1159/000430197.

154. Burchfield JS, Iwasaki M, Koyanagi M, Urbich C, Rosenthal N, Zeiher AM, Dimmeler S. Interleukin-10 from transplanted bone marrow mononuclear cells contributes to cardiac protection after myocardial infarction. Circ Res. 2008; 103:203-11. https://doi.org/10.1161/ circresaha.108.178475.

155. Kelly J, Ali Khan A, Yin J, Ferguson TA, Apte RS. Senescence regulates macrophage activation and angiogenic fate at sites of tissue injury in mice. J Clin Invest. 2007; 117:3421-6. https://doi.org/10.1172/jci32430.

156. Frangogiannis NG. Targeting the inflammatory response in healing myocardial infarcts. Curr Med Chem. 2006; 13:1877-93.

157. Apte RS, Richter J, Herndon J, Ferguson TA. Macrophages inhibit neovascularization in a murine model of age-related macular degeneration. PLoS Med. 2006; 3:e310. https://doi. org/10.1371/journal.pmed.0030310.

158. Frangogiannis NG, Mendoza LH, Lindsey ML, Ballantyne CM, Michael LH, Smith CW, Entman ML. 
IL-10 is induced in the reperfused myocardium and may modulate the reaction to injury. J Immunol. 2000; 165:2798-808.

159. Krishnamurthy P, Rajasingh J, Lambers E, Qin G, Losordo DW, Kishore R. IL-10 inhibits inflammation and attenuates left ventricular remodeling after myocardial infarction via activation of STAT3 and suppression of HuR. Circ Res. 2009; 104:e9-18. https://doi.org/10.1161/ circresaha.108.188243.

160. Krishnamurthy P, Thal M, Verma S, Hoxha E, Lambers E, Ramirez V, Qin G, Losordo D, Kishore R. Interleukin-10 deficiency impairs bone marrow-derived endothelial progenitor cell survival and function in ischemic myocardium. Circ Res. 2011; 109:1280-9. https://doi. org/10.1161/circresaha.111.248369.

161. Koscso B, Csoka B, Kokai E, Nemeth ZH, Pacher P, Virag L, Leibovich SJ, Hasko G. Adenosine augments IL-10-induced STAT3 signaling in M2c macrophages. J Leukoc Biol. 2013; 94:1309-15. https://doi.org/10.1189/ jlb.0113043.

162. Dace DS, Khan AA, Kelly J, Apte RS. Interleukin-10 promotes pathological angiogenesis by regulating macrophage response to hypoxia during development. PLoS One. 2008; 3:e3381. https://doi.org/10.1371/journal. pone.0003381.

163. Nakamura R, Sene A, Santeford A, Gdoura A, Kubota S, Zapata N, Apte RS. IL10-driven STAT3 signalling in senescent macrophages promotes pathological eye angiogenesis. Nat Commun. 2015; 6:7847. https://doi. org/10.1038/ncomms8847.

164. Oral HB, Kotenko SV, Yilmaz M, Mani O, Zumkehr J, Blaser K, Akdis CA, Akdis M. Regulation of T cells and cytokines by the interleukin-10 (IL-10)-family cytokines IL-19, IL-20, IL-22, IL-24 and IL-26. Eur J Immunol. 2006; 36:380-8. https://doi.org/10.1002/eji.200425523.

165. Pestka S, Krause CD, Sarkar D, Walter MR, Shi Y, Fisher PB. Interleukin-10 and related cytokines and receptors. Annu Rev Immunol. 2004; 22:929-79. https:// doi.org/10.1146/annurev.immunol.22.012703.104622.

166. Kako F, Gabunia K, Ray M, Kelemen SE, England RN, Kako B, Scalia RG, Autieri MV. Interleukin-19 induces angiogenesis in the absence of hypoxia by direct and indirect immune mechanisms. Am J Physiol Cell Physiol. 2016; 310:C931-41. https://doi.org/10.1152/ ajpcell.00006.2016.

167. Jiang R, Tan Z, Deng L, Chen Y, Xia Y, Gao Y, Wang X, Sun B. Interleukin-22 promotes human hepatocellular carcinoma by activation of STAT3. Hepatology. 2011; 54:900-9. https://doi.org/10.1002/hep.24486.

168. Xiao W, Wu K, Yin M, Han S, Ding Y, Qiao A, Lu G, Deng B, Bo P, Gong W. Wogonin Inhibits Tumor-derived Regulatory Molecules by Suppressing STAT3 Signaling to Promote Tumor Immunity. J Immunother. 2015; 38:167-84. https://doi.org/10.1097/cji.0000000000000080.
169. Park S, Kim JK, Oh CJ, Choi SH, Jeon JH, Lee IK. Scoparone interferes with STAT3-induced proliferation of vascular smooth muscle cells. Exp Mol Med. 2015; 47:e145. https://doi.org/10.1038/emm.2014.113.

170. Kowshik J, Baba AB, Giri H, Deepak Reddy G, Dixit M, Nagini S. Astaxanthin inhibits JAK/STAT-3 signaling to abrogate cell proliferation, invasion and angiogenesis in a hamster model of oral cancer. PLoS One. 2014; 9:e109114. https://doi.org/10.1371/journal.pone.0109114.

171. Tanaka T, Shnimizu M, Moriwaki H. Cancer chemoprevention by carotenoids. Molecules. 2012; 17:3202-42. https://doi.org/10.3390/molecules17033202.

172. Li-Weber M. New therapeutic aspects of flavones: the anticancer properties of Scutellaria and its main active constituents Wogonin, Baicalein and Baicalin. Cancer Treat Rev. 2009; 35:57-68. https://doi.org/10.1016/j. ctrv.2008.09.005.

173. Cheng Y, Li Y, Nian Y, Liu D, Dai F, Zhang J. STAT3 is involved in miR-124-mediated suppressive effects on esophageal cancer cells. BMC Cancer. 2015; 15:306. https://doi.org/10.1186/s12885-015-1303-0.

174. Koukos G, Polytarchou C, Kaplan JL, Morley-Fletcher A, Gras-Miralles B, Kokkotou E, Baril-Dore M, Pothoulakis C, Winter HS, Iliopoulos D. MicroRNA-124 regulates STAT3 expression and is down-regulated in colon tissues of pediatric patients with ulcerative colitis. Gastroenterology. 2013; 145:842-52.e2. https://doi.org/10.1053/j. gastro.2013.07.001.

175. Yan L, Hao H, Elton TS, Liu Z, Ou H. Intronic microRNA suppresses endothelial nitric oxide synthase expression and endothelial cell proliferation via inhibition of STAT3 signaling. Mol Cell Biochem. 2011; 357:9-19. https://doi. org/10.1007/s11010-011-0870-x.

176. Sathyanarayanan A, Chandrasekaran KS, Karunagaran D. microRNA-146a inhibits proliferation, migration and invasion of human cervical and colorectal cancer cells. Biochem Biophys Res Commun. 2016; 480:528-33. https:// doi.org/10.1016/j.bbrc.2016.10.054.

177. Kim BH, Lee Y, Yoo H, Cui M, Lee S, Kim SY, Cho JU, Lee H, Yang BS, Kwon YG, Choi S, Kim TY. Antiangiogenic activity of thienopyridine derivative LCB030110 by targeting VEGFR-2 and JAK/STAT3 Signalling. Exp Dermatol. 2015; 24:503-9. https://doi.org/10.1111/ exd.12698.

178. Zhang X, Song Y, Wu Y, Dong Y, Lai L, Zhang J, Lu B, Dai F, He L, Liu M, Yi Z. Indirubin inhibits tumor growth by antitumor angiogenesis via blocking VEGFR2-mediated JAK/STAT3 signaling in endothelial cell. Int J Cancer. 2011; 129:2502-11. https://doi.org/10.1002/ijc.25909.

179. Liau BC, Jong TT, Lee MR, Chen SS. LC-APCI-MS method for detection and analysis of tryptanthrin, indigo, and indirubin in daqingye and banlangen. J Pharm Biomed Anal. 2007; 43:346-51. https://doi.org/10.1016/j. jpba.2006.06.029. 
180. Zhou W, Bi X, Gao G, Sun L. miRNA-133b and miRNA135a induce apoptosis via the JAK2/STAT3 signaling pathway in human renal carcinoma cells. Biomed Pharmacother. 2016; 84:722-9. https://doi.org/10.1016/j. biopha.2016.09.074.

181. Yu B, Lv X, Su L, Li J, Yu Y, Gu Q, Yan M, Zhu Z, Liu B. MiR-148a Functions as a Tumor Suppressor by Targeting CCK-BR via Inactivating STAT3 and Akt in Human Gastric Cancer. PLoS One. 2016; 11:e0158961. https://doi. org/10.1371/journal.pone.0158961.

182. Hung SC, Kuo KL, Huang HL, Lin CC, Tsai TH, Wang CH, Chen JW, Lin SJ, Huang PH, Tarng DC. Indoxyl sulfate suppresses endothelial progenitor cell-mediated neovascularization. Kidney Int. 2016; 89:574-85. https:// doi.org/10.1016/j.kint.2015.11.020.

183. Qi J, Xia G, Huang CR, Wang JX, Zhang J. JSI-124 (Cucurbitacin I) inhibits tumor angiogenesis of human breast cancer through reduction of STAT3 phosphorylation. Am J Chin Med. 2015; 43:337-47. https://doi.org/10.1142/ s0192415x15500226.

184. Zhang Z, Wang F, Wang BJ, Chu G, Cao Q, Sun BG, Dai QY. Inhibition of leptin-induced vascular extracellular matrix remodelling by adiponectin. J Mol Endocrinol. 2014; 53:145-54. https://doi.org/10.1530/jme-14-0027.

185. Godse P, Kumar P, Yewalkar N, Deore V, Lohar M, Mundada R, Padgaonkar A, Manohar S, Joshi A, Bhatia D, Desai N, Damre A, Bhonde M, et al. Discovery of P3971 an orally efficacious novel anticancer agent targeting HIF1alpha and STAT3 pathways. Anticancer Agents Med Chem. 2013; 13:1460-6.

186. Carbajo-Pescador S, Ordonez R, Benet M, Jover R, GarciaPalomo A, Mauriz JL, Gonzalez-Gallego J. Inhibition of VEGF expression through blockade of Hiflalpha and STAT3 signalling mediates the anti-angiogenic effect of melatonin in HepG2 liver cancer cells. Br J Cancer. 2013; 109:83-91. https://doi.org/10.1038/bjc.2013.285.

187. Bhat TA, Nambiar D, Tailor D, Pal A, Agarwal R, Singh RP. Acacetin inhibits in vitro and in vivo angiogenesis and downregulates Stat signaling and VEGF expression. Cancer Prev Res (Phila). 2013; 6:1128-39. https://doi. org/10.1158/1940-6207.capr-13-0209.

188. Haghikia A, Missol-Kolka E, Tsikas D, Venturini L, Brundiers S, Castoldi M, Muckenthaler MU, Eder M, Stapel B, Thum T, Haghikia A, Petrasch-Parwez E, Drexler H, et al. Signal transducer and activator of transcription 3-mediated regulation of miR-199a-5p links cardiomyocyte and endothelial cell function in the heart: a key role for ubiquitin-conjugating enzymes. Eur Heart J. 2011; 32:1287-97. https://doi.org/10.1093/eurheartj/ehq369.

189. Tritsaris K, Myren M, Ditlev SB, Hubschmann MV, van der Blom I, Hansen AJ, Olsen UB, Cao R, Zhang J, Jia T, Wahlberg E, Dissing S, Cao Y. IL-20 is an arteriogenic cytokine that remodels collateral networks and improves functions of ischemic hind limbs. Proc Natl Acad Sci USA. 2007; 104:15364-9. https://doi.org/10.1073/pnas.0707302104.
190. Chen H, Guan Y, Yuan G, Zhang Q, Jing N. A perylene derivative regulates HIF-1alpha and Stat3 signaling pathways. Bioorg Med Chem. 2014; 22:1496-505. https:// doi.org/10.1016/j.bmc.2013.10.018.

191. Li S, Priceman SJ, Xin H, Zhang W, Deng J, Liu Y, Huang J, Zhu W, Chen M, Hu W, Deng X, Zhang J, Yu H, et al. Icaritin inhibits JAK/STAT3 signaling and growth of renal cell carcinoma. PLoS One. 2013; 8:e81657. https:// doi.org/10.1371/journal.pone.0081657.

192. Qin Z, Wan JJ, Sun Y, Wu T, Wang PY, Du P, Su DF, Yang Y, Liu X. Nicotine protects against DSS colitis through regulating microRNA-124 and STAT3. J Mol Med (Berl). 2017; 95:221-33. https://doi.org/10.1007/s00109-0161473-5.

193. Zhang Y, Liu Y, Zhang H, Wang M, Zhang J. Mmu-miR-351 attenuates the survival of cardiac arterial endothelial cells through targeting STAT3 in the atherosclerotic mice. Biochem Biophys Res Commun. 2015; 468:300-5. https:// doi.org/10.1016/j.bbrc.2015.10.108.

194. Sun CC, Li SJ, Zhang F, Zhang YD, Zuo ZY, Xi YY, Wang L, Li DJ. The Novel miR-9600 Suppresses Tumor Progression and Promotes Paclitaxel Sensitivity in Non-small-cell Lung Cancer Through Altering STAT3 Expression. Mol Ther Nucleic Acids. 2016; 5:e387. https:// doi.org/10.1038/mtna.2016.96.

195. Lu S, Gao Y, Huang X, Wang X. GYY4137, a hydrogen sulfide $(\mathrm{H}(2) \mathrm{S})$ donor, shows potent anti-hepatocellular carcinoma activity through blocking the STAT3 pathway. Int J Oncol. 2014; 44:1259-67. https://doi.org/10.3892/ ijo.2014.2305.

196. Liu X, Zhang A, Xiang J, Lv Y, Zhang X. miR-451 acts as a suppressor of angiogenesis in hepatocellular carcinoma by targeting the IL-6R-STAT3 pathway. Oncol Rep. 2016; 36:1385-92. https://doi.org/10.3892/or.2016.4971.

197. Wang L, Zhuang L, Rong H, Guo Y, Ling X, Wang R, Yu X, Zhang W. MicroRNA-101 inhibits proliferation of pulmonary microvascular endothelial cells in a rat model of hepatopulmonary syndrome by targeting the JAK2/STAT3 signaling pathway. Mol Med Rep. 2015; 12:8261-7. https:// doi.org/10.3892/mmr.2015.4471.

198. Saydmohammed M, Joseph D, Syed V. Curcumin suppresses constitutive activation of STAT-3 by upregulating protein inhibitor of activated STAT-3 (PIAS-3) in ovarian and endometrial cancer cells. J Cell Biochem. 2010; 110:447-56. https://doi.org/10.1002/jcb.22558.

199. Pandey MK, Sung B, Ahn KS, Aggarwal BB. Butein suppresses constitutive and inducible signal transducer and activator of transcription (STAT) 3 activation and STAT3-regulated gene products through the induction of a protein tyrosine phosphatase SHP-1. Mol Pharmacol. 2009; 75:525-33. https://doi.org/10.1124/mol.108.052548.

200. Kunnumakkara AB, Nair AS, Sung B, Pandey MK, Aggarwal BB. Boswellic acid blocks signal transducers and activators of transcription 3 signaling, proliferation, and survival of multiple myeloma via the protein tyrosine 
phosphatase SHP-1. Mol Cancer Res. 2009; 7:118-28. https://doi.org/10.1158/1541-7786.mcr-08-0154.

201. Zhang P, Yang B, Yao YY, Zhong LX, Chen XY, Kong QY, Wu ML, Li C, Li H, Liu J. PIAS3, SHP2 and SOCS3 Expression patterns in Cervical Cancers: Relevance with activation and resveratrol-caused inactivation of STAT3 signaling. Gynecol Oncol. 2015; 139:529-35. https://doi. org/10.1016/j.ygyno.2015.09.087.

202. Tang Q, Li G, Wei X, Zhang J, Chiu JF, Hasenmayer D, Zhang D, Zhang H. Resveratrol-induced apoptosis is enhanced by inhibition of autophagy in esophageal squamous cell carcinoma. Cancer Lett. 2013; 336:325-37. https://doi.org/10.1016/j.canlet.2013.03.023.

203. Li YG, Xia HJ, Tao JP, Xin P, Liu MY, Li JB, Zhu W, Wei M. GRIM19mediated Stat3 activation is a determinant for resveratrolinduced proliferation and cytotoxicity in cervical tumorderived cell lines. Mol Med Rep. 2015; 11:1272-7. https://doi.org/10.3892/mmr.2014.2797.
204. Nallar SC, Kalakonda S, Lindner DJ, Lorenz RR, Lamarre E, Weihua X, Kalvakolanu DV. Tumor-derived mutations in the gene associated with retinoid interferoninduced mortality (GRIM-19) disrupt its anti-signal transducer and activator of transcription 3 (STAT3) activity and promote oncogenesis. J Biol Chem. 2013; 288:793041. https://doi.org/10.1074/jbc.M112.440610.

205. Wen Z, Huang C, Xu Y, Xiao Y, Tang L, Dai J, Sun H, Chen B, Zhou M. alpha-Solanine inhibits vascular endothelial growth factor expression by down-regulating the ERK1/2-HIF-1alpha and STAT3 signaling pathways. Eur J Pharmacol. 2016; 771:93-8. https://doi.org/10.1016/j. ejphar.2015.12.020.

206. Zhu C, Zhou R, Zhou Q, Chang Y, Jiang M. microRNA-539 suppresses tumor growth and tumorigenesis and overcomes arsenic trioxide resistance in hepatocellular carcinoma. Life Sci. 2016; 166:34-40. https://doi.org/10.1016/j. lfs.2016.10.002 